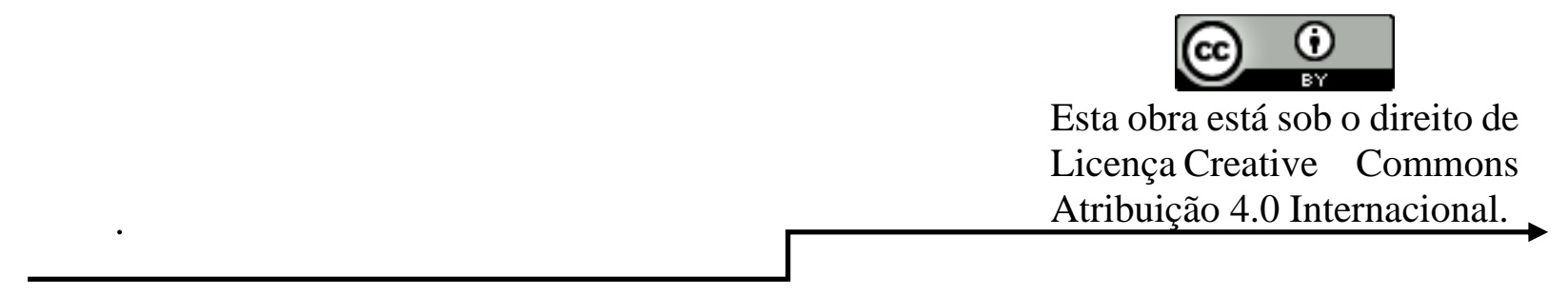

\title{
BIBLIOMETRIA APLICADA À PRODUÇÃO CIENTÍFICA DO CAMPO PSICOLOGIA ESCOLAR NO ENSINO SUPERIOR
}

\section{BIBLIOMETRICS APPLIED TO SCIENTIFIC PRODUCTION IN THE SCHOOL PSYCHOLOGY FIEL IN HIGHER EDUCATION}

\author{
Eliane Reis Neves da Silval \\ Andrea Marques Vanderlei Fregadolli2 \\ Betijane Soares de Barros ${ }^{3}$ \\ Eduardo Cabral da Silva ${ }^{4}$
}

\section{RESUMO}

O presente estudo conceitua o que é bibliometria citando alguns autores. Tem como objetivo identificar o padrão de produção científica no Campo Psicologia Escolar no Ensino Superior. Do ponto de vista metodológico foram combinados dois tipos de abordagens: a análise bibliométrica e a análise de conteúdo a partir de um estudo bibliométrico quantitativo baseado nos 22 artigos referente a temática Psicólogo Escolar e sua Atuação frente as Metamorfoses do Ensino Superior, para serem analisados pelo Protocolo Eletrônico de Estudos Bibliométricos adaptado para a atual pesquisa constituído por um Formulário Eletrônico com 20 perguntas. Os resultados obtidos foram analisados em relação às 18 categorias que acopladas finalizou com 12 categorias. Conclui-se que os dados contidos neste estudo podem ser utilizados como ferramenta por reconhecer que o Estudo Bibliométrico é um dos métodos importantes para apresentar o estágio em que a pesquisa se encontra em uma determinada área e revelam-se eficientes quando os dados são detalhadamente trabalhados e eficazes quando cautelosamente analisados.

Palavras - Chave: Bibliometria. Produção Científica. Categorias.

\begin{abstract}
The present study conceptualizes bibliometrics, citing some authors. It aims to identify the pattern of scientific production in the field of School Psychology in Higher Education. From the methodological point of view, two types of approaches were combined: bibliometric analysis and content analysis based on a quantitative bibliometric study based on the 22 articles on the theme School Psychologist and his Performance in the Higher Education
\end{abstract}

\footnotetext{
1 elianereis@uol.com.br

2 deadoutorado@hotmail.com

${ }^{3}$ Bj-sb@hotmail.com

${ }^{4}$ Edcs.cabral@gmail.com
} 
Metamorphoses, to be analyzed by Electronic Protocol of Bibliometric Studies adapted for the current research, constituted by an Electronic Form with 20 questions. The results obtained were analyzed in relation to the 18 categories that coupled ended with 12 categories. It is concluded that the data contained in this study can be used as a tool because it recognizes that the Bibliometric Study is one of the important methods to present the stage in which the research is in a certain area and prove to be efficient when the data are worked out in detail. and effective when carefully analyzed.

Palavras-chave: Bibliometry. Scientific production. CALL US. 


\section{INTRODUÇÃO}

A eclosão da bibliometria tem contribuído para a mensuração e compreensão da evolução das produções de conhecimentos científicos, e da avaliação das atividades intelectuais de pesquisadores e estudiosos, com base em técnicas quantitativas e estatísticas. Além disso, possibilita o reconhecimento dos escritores e a exposição da literatura existente se torna relevante nas diversas áreas de pesquisa. (PIMENTA, PORTELA, OLIVEIRA e RIBEIRO, 2017)

Andrés (2009) complementa a definição do conceito de bibliometria, afirmando que a produção científica de qualquer campo pode ser analisada a partir da utilização de técnicas bibliométricas; o único pré requisito é que se possua um conjunto adequado de publicações. $\mathrm{Na}$ bibliometria são utilizados diversos indicadores para estudar a produção científica, as relações e interações entre seus elementos (MARICATO, 2011).

\section{METODOOGIA}

A bibliometria auxilia na verificação de muitos aspectos da comunicação científica e tecnológica; se mostra excelente ferramenta para conhecer o estado da arte das áreas do conhecimento em seus recortes específico (JOB, 2018).
O presente artigo busca responder a questão: Qual o padrão de produção científica no Campo Psicologia Escolar no Ensino Superior no período de 2013 a 2020 ? Para isso se propôs no procedimento metodológico aplicar o Protocolo Eletrônico de Estudos Bibliométricos nos 22 artigos referente a temática Psicólogo Escolar e sua Atuação frente as Metamorfoses do Ensino Superior para identificar as categorias e analisar os parâmetros apresentados pela bibliometria para a produção científica.

O Protocolo Eletrônico de Estudos Bibliométricos é formado por 72 perguntas, da qual extraiu-se 20 perguntas, adaptando assim o protocolo para esta pesquisa. Dessas 20 perguntas retirou-se 12 variáveis para serem discutidas nesta pesquisa. Tendo como objetivo identificar através do estudo Bibliométrico o padrão de produção científica no Campo Psicologia Escolar no Ensino Superior.

Os 22 artigos submetidos ao estudo bibliométrico foram oriundos da Pesquisa 1. Segue, no Quadro 1, o detalhamento das etapas de Revisão Sistemática Integrativa que nortearam o planejamento do estudo bibliométrico. 
Quadro 1 - Detalhamento das etapas do Estudo Bibliométrico

\begin{tabular}{|c|c|c|}
\hline ETAPAS & $\begin{array}{l}\text { TÓPICOS DE CADA } \\
\text { ETAPA }\end{array}$ & DETALHAMENTO DE CADA TÓPICO \\
\hline \multirow[t]{3}{*}{$1^{\mathrm{a}}$} & Tema & $\begin{array}{l}\text { Bibliometria aplicada à produção científica do campo } \\
\text { Psicologia Escolar no Ensino Superior }\end{array}$ \\
\hline & Pergunta Norteadora & $\begin{array}{l}\text { Através do Estudo Bibliométrico é possível } \\
\text { identificar o padrão de produção científica no Campo } \\
\text { Psicologia Escolar no Ensino Superior? }\end{array}$ \\
\hline & Objetivo Geral & $\begin{array}{l}\text { Identificar através da bibliometria o padrão de } \\
\text { produção científica no Campo Psicologia Escolar no } \\
\text { Ensino Superior }\end{array}$ \\
\hline \multirow[t]{3}{*}{$2^{a}$} & Estratégias de busca & $\begin{array}{l}\text { Interrogar os } 22 \text { artigos científicos obtidos na } \\
\text { Revisão Sistemática Integrativa (Pesquisa 1) por } \\
\text { meio do Protocolo Eletrônico de Estudos } \\
\text { Bibliométricos (PEEB) }\end{array}$ \\
\hline & Critérios de inclusão & Artigos no período de 2013 a 2019 \\
\hline & $\begin{array}{l}\text { Trabalhos selecionados para } \\
\text { serem analisados através do } \\
\text { Protocolo de Estudos } \\
\text { Bibliométricos }\end{array}$ & 22 \\
\hline $3^{a}$ & $\begin{array}{l}\text { Categorias obtidas com a } \\
\text { análise dos trabalhos } \\
\text { científicos investigados }\end{array}$ & $\begin{array}{l}\text { Versão/Idioma/Páginas; Publicação/autoria e } \\
\text { coautoria; Qualis; Palavras-chave; Referências } \\
\text { bibliográficas; Artigo/Tipo; Revista/Periódico; } \\
\text { Submissão/Aceite/Publicação; Função do autor; } \\
\text { Titulação do autor; Linha de Pesquisa/Objetivo } \\
\text { Geral. }\end{array}$ \\
\hline $4^{\mathrm{a}}$ & & Ver em "Resultados e Discussão" \\
\hline $5^{\mathrm{a}}$ & $\begin{array}{l}\text { Apresentação da revisão em } \\
\text { formato de artigo, o qual } \\
\text { contemple propostas para } \\
\text { estudos futuros. }\end{array}$ & Esse artigo completo \\
\hline
\end{tabular}

Fonte: Autoria própria.

QLScrJ_z19uYc8YR_Ai0ztVvRmkG0MB

O escopo desta pesquisa foi mobilizar os

22 artigos publicados no período de 2013

a 2020, submetidos a Revisão Sistemática

Integrativa acerca da temática Atuação do

Psicólogo Escolar no Ensino Superior para serem analisados pelo Protocolo Eletrônico de Estudos Bibliométricos (PEEB), ferramenta do Google Drive em formato de Formulário Eletrônico, disponibilizada pelo link https://docs.google.com/forms/d/e/1FAIp
g-gzsR5leEFuao7Smrug/viewform.

$\mathrm{O}$ instrumento interrogativo validado está dividido em duas partes, sendo a primeira parte contendo 31 perguntas, a segunda parte contendo 40 perguntas, totalizando 71 perguntas e acrescentado um espaço para críticas e sugestões com o objetivo de melhorar o formulário. Trata-se de um instrumento semiestruturado com perguntas objetivas e subjetivas. 
Entretanto neste artigo foi feita perguntas objetivas e subjetivas. uma adaptação do Protocolo Eletrônico de https://docs.google.com/forms/d/e/1FAIp Estudo Bibliométrico (PEEB), elaborado QLSeJCujxBY_RydNxEkpzUaaAPS2cgk pela própria autora deste artigo utilizando 3Hwu8arOoaEvTk3nEMwQ/formRespon 20 perguntas tratando-se de um se. instrumento semiestruturado por obter

Figura 1 - Formulário do Protocolo Eletrônico de Estudo Bibliométrico

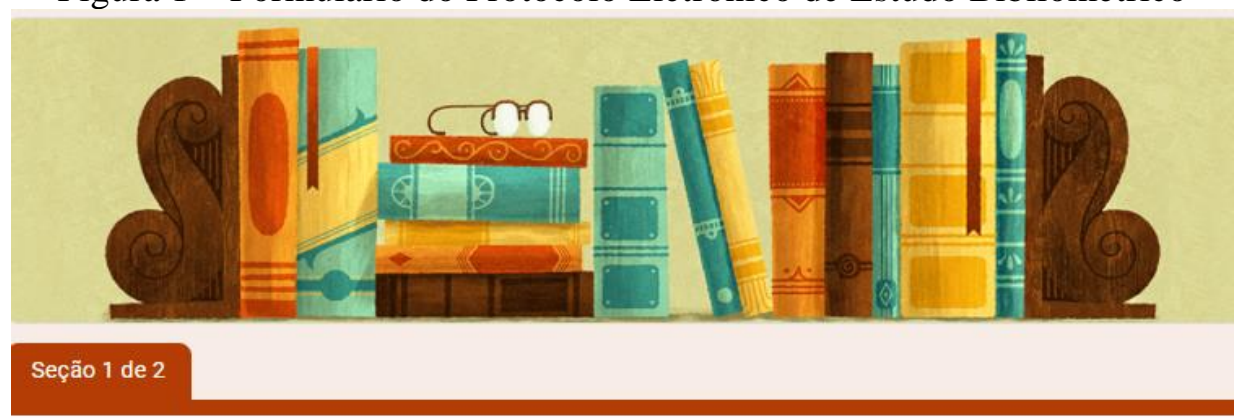

Protocolo Eletrônico de Estudos Bibliométricos

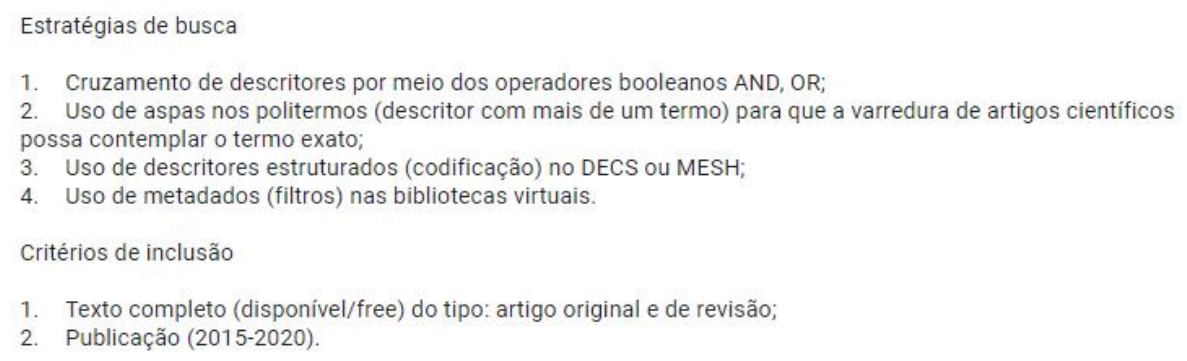

As strings utilizadas nesta busca

Os artigos analisados foram obtidos das bases de dados SciELO (Scientific Eletronic Library Online), LILACS (Literatura Latino-Americana e do Caribe e Ciências da Saúde), BVS (Biblioteca Virtual em Saúde), Willey (Online Library) e PubMed Tools, período de 2013 a 2019. foram: "Psicólogo Escolar", "Psicólogo Educacional", "Psicologia Escolar", "Ensino Superior", "Educação Superior" e “Atuação do Psicólogo" e levaram em consideração como fator de exclusão os critérios artigos repetidos, artigos que não contemplam a temática abordada. 


\section{RESULTADOS}

Os resultados são gerados em torno

da análise realizada através do Protocolo de Estudos Bibliométricos dos 22 artigos referente a temática Psicólogo Escolar e sua Atuação frente as Metamorfoses do Ensino Superior (Quadro 2)

Quadro 2. Levantamento descritivo dos 22 artigos referente a temática Atuação do Psicólogo Escolar frente as Metamorfoses do Ensino Superior.

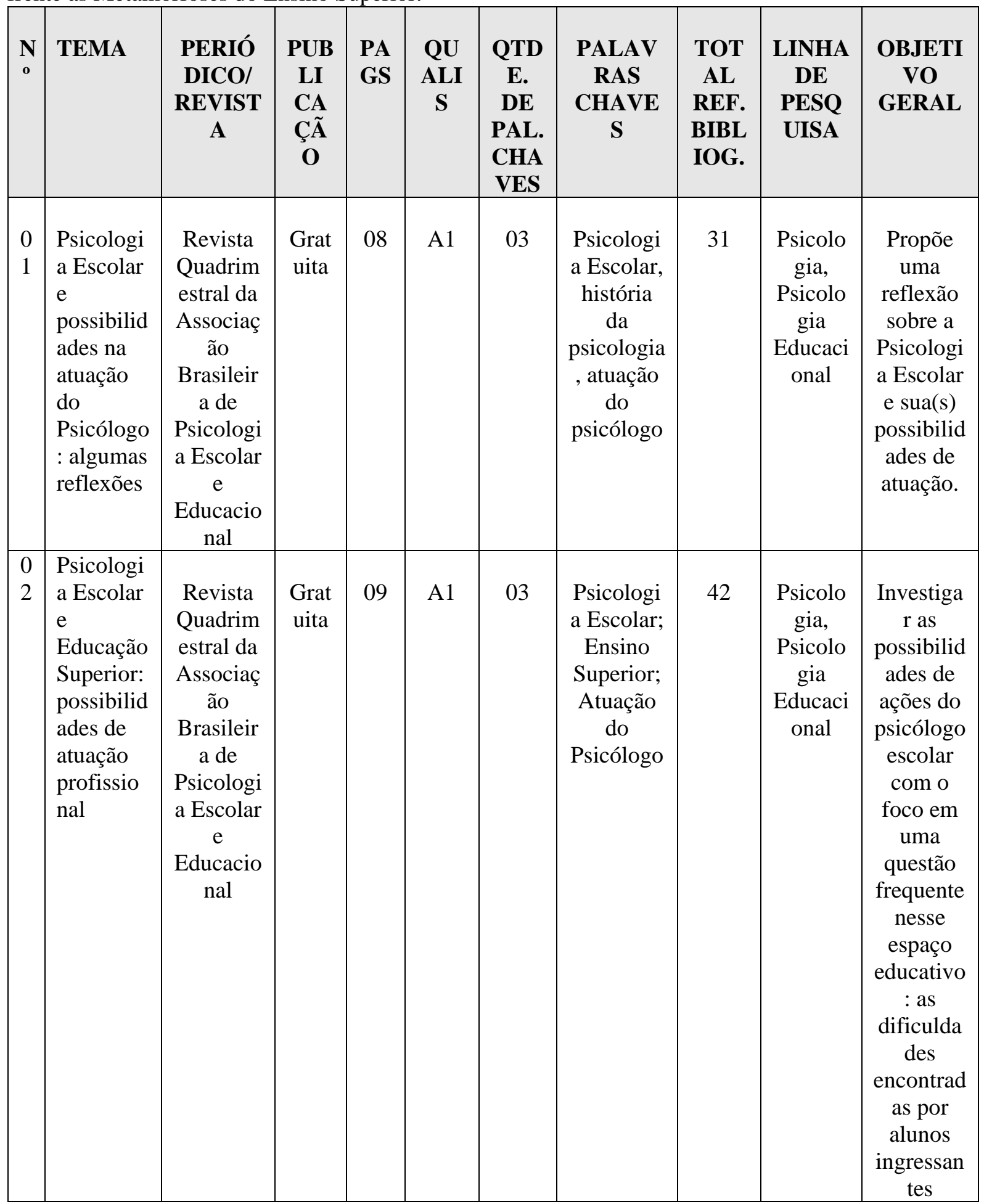




\begin{tabular}{|c|c|c|c|c|c|c|c|c|c|c|}
\hline $\begin{array}{l}0 \\
3\end{array}$ & $\begin{array}{l}\text { Psicologi } \\
\text { a Escolar } \\
\text { na } \\
\text { Educação } \\
\text { Superior: } \\
\text { panorama } \\
\text { da } \\
\text { atuação } \\
\text { no Brasil. }\end{array}$ & $\begin{array}{l}\text { Arquivos } \\
\text { Brasileir } \\
\text { os de } \\
\text { Psicologi } \\
\text { a }\end{array}$ & $\begin{array}{l}\text { Grat } \\
\text { uita }\end{array}$ & 14 & A2 & 04 & $\begin{array}{c}\text { Psicologi } \\
\text { a escolar; } \\
\text { Ensino } \\
\text { superior; } \\
\text { Atuação } \\
\text { emergent } \\
\text { e; Modelo } \\
\text { de } \\
\text { Atuação. }\end{array}$ & 40 & $\begin{array}{l}\text { Psicolo } \\
\text { gia, } \\
\text { Psicolo } \\
\text { gia } \\
\text { Educaci } \\
\text { onal }\end{array}$ & $\begin{array}{c}\text { Traçar } \\
\text { um } \\
\text { panorama } \\
\text { de como } \\
\text { está } \\
\text { atualment } \\
\text { e } \\
\text { desenhad } \\
\text { a a } \\
\text { presença } \\
\text { da } \\
\text { Psicologi } \\
\text { a Escolar } \\
\text { na } \\
\text { Educação } \\
\text { Superior } \\
\text { no país. }\end{array}$ \\
\hline $\begin{array}{l}0 \\
4\end{array}$ & $\begin{array}{l}\text { Atuação } \\
\text { do } \\
\text { Psicólogo } \\
\text { Escolar e } \\
\text { Educacio } \\
\text { nal no } \\
\text { ensino } \\
\text { superior; } \\
\text { reflexões } \\
\text { sobre } \\
\text { práticas }\end{array}$ & $\begin{array}{c}\text { Associaç } \\
\text { ão } \\
\text { Brasileir } \\
\text { a de } \\
\text { Psicologi } \\
\text { a Escolar } \\
e \\
\text { Educacio } \\
\text { nal } \\
\text { (ABRAP } \\
\text { EE) }\end{array}$ & $\begin{array}{l}\text { Grat } \\
\text { uita }\end{array}$ & 10 & A1 & 03 & $\begin{array}{c}\text { Psicologi } \\
\text { a Escolar; } \\
\text { atuação } \\
\text { do } \\
\text { psicólogo } \\
; \\
\text { ambiente } \\
\text { universitá } \\
\text { rio. }\end{array}$ & 46 & $\begin{array}{l}\text { Psicolo } \\
\text { gia, } \\
\text { Psicolo } \\
\text { gia } \\
\text { Educaci } \\
\text { onal }\end{array}$ & $\begin{array}{c}\text { Refletir } \\
\text { sobre o } \\
\text { trabalho } \\
\text { desenvol } \\
\text { vido por } \\
\text { psicólogo } \\
\text { s no } \\
\text { contexto } \\
\text { das } \\
\text { Instituiçõ } \\
\text { es de } \\
\text { Ensino } \\
\text { Superior. }\end{array}$ \\
\hline $\begin{array}{l}0 \\
5\end{array}$ & $\begin{array}{l}\text { A } \\
\text { atuação } \\
\text { do } \\
\text { Psicólogo } \\
\text { Escolar } \\
\text { no } \\
\text { Ensino } \\
\text { Superior: } \\
\text { Configur } \\
\text { ações, } \\
\text { desafios } \\
\text { e } \\
\text { proposiçõ } \\
\text { es sobre } \\
\text { o } \\
\text { fracasso } \\
\text { escolar }\end{array}$ & $\begin{array}{c}\text { Revista } \\
\text { Quadrim } \\
\text { estral da } \\
\text { Associaç } \\
\text { ão } \\
\text { Brasileir } \\
\text { a de } \\
\text { Psicologi } \\
\text { a Escolar } \\
\text { e } \\
\text { Educacio } \\
\text { nal }\end{array}$ & $\begin{array}{l}\text { Grat } \\
\text { uita }\end{array}$ & 12 & A1 & 03 & $\begin{array}{c}\text { Ensino } \\
\text { Superior; } \\
\text { Psicologi } \\
\text { a Escolar; } \\
\text { Psicologi } \\
\text { a } \\
\text { Histórico- } \\
\text { Cultural. }\end{array}$ & 38 & $\begin{array}{l}\text { Educaç } \\
\text { ão; } \\
\text { Educaç } \\
\text { ão }\end{array}$ & $\begin{array}{c}\text { Analisar } \\
\text { a atuação } \\
\text { do } \\
\text { psicólogo } \\
\text { escolar } \\
\text { no } \\
\text { Ensino } \\
\text { Superior } \\
\text { e o } \\
\text { posiciona } \\
\text { mento } \\
\text { que este } \\
\text { profissio } \\
\text { nal } \\
\text { assume } \\
\text { diante } \\
\text { do } \\
\text { fracasso } \\
\text { escolar, a } \\
\text { partir dos } \\
\text { fundame }\end{array}$ \\
\hline
\end{tabular}




\begin{tabular}{|c|c|c|c|c|c|c|c|c|c|c|}
\hline & & & & & & & & & & $\begin{array}{c}\text { ntos da } \\
\text { Psicologi } \\
\text { a } \\
\text { Histórico } \\
\text {-Cultural. }\end{array}$ \\
\hline $\begin{array}{l}0 \\
6\end{array}$ & \begin{tabular}{|l} 
Atuação \\
dos \\
Psicólogo \\
s nos \\
"núcleos \\
de \\
acessibili \\
dade" das \\
universid \\
ades \\
federais \\
brasileira \\
s
\end{tabular} & $\begin{array}{c}\text { Revista } \\
\text { Quadrim } \\
\text { estral da } \\
\text { Associaç } \\
\text { ão } \\
\text { Brasileir } \\
\text { a de } \\
\text { Psicologi } \\
\text { a Escolar } \\
\text { e } \\
\text { Educacio } \\
\text { nal }\end{array}$ & $\begin{array}{l}\text { Grat } \\
\text { uita }\end{array}$ & 10 & A1 & 03 & $\begin{array}{l}\text { Acessibili } \\
\text { dade; } \\
\text { Educação } \\
\text { Especial; } \\
\text { Psicologi } \\
\text { a. }\end{array}$ & 27 & $\begin{array}{c}\text { Educaç } \\
\text { ão; } \\
\text { Educaç } \\
\text { ão } \\
\text { Especia } \\
1\end{array}$ & $\begin{array}{c}\text { Propõe } \\
\text { identifica } \\
\text { r e } \\
\text { discutir } \\
\text { as ações } \\
\text { da } \\
\text { Psicologi } \\
\text { a nos } \\
\text { núcleos } \\
\text { de } \\
\text { acessibili } \\
\text { dades, } \\
\text { em } \\
\text { especial } \\
\text { averiguar } \\
\text { como } \\
\text { seus } \\
\text { coordena } \\
\text { dores se } \\
\text { manifesta } \\
\text { m diante } \\
\text { desse } \\
\text { processo. }\end{array}$ \\
\hline $\begin{array}{l}0 \\
7\end{array}$ & $\begin{array}{l}\text { A } \\
\text { Atividade } \\
\text { criadora } \\
\text { do } \\
\text { Psicólogo } \\
\text { Escolar } \\
\text { na } \\
\text { Educação } \\
\text { Superior, }\end{array}$ & $\begin{array}{c}\text { Revista } \\
\text { Quadrim } \\
\text { estral da } \\
\text { Associaç } \\
\text { ão } \\
\text { Brasileir } \\
\text { a de } \\
\text { Psicologi } \\
\text { a Escolar } \\
\text { e } \\
\text { Educacio } \\
\text { nal }\end{array}$ & $\begin{array}{l}\text { Grat } \\
\text { uita }\end{array}$ & 07 & A1 & 03 & $\begin{array}{l}\text { Psicologi } \\
\text { a escolar; } \\
\text { criação; } \\
\text { educação } \\
\text { superior }\end{array}$ & 28 & $\begin{array}{l}\text { Psicolo } \\
\text { gia; } \\
\text { Psicolo } \\
\text { gia } \\
\text { Educaci } \\
\text { onal }\end{array}$ & $\begin{array}{c}\text { Apresent } \\
\text { ar uma } \\
\text { reflexão } \\
\text { teórica } \\
\text { sobre a } \\
\text { ação } \\
\text { profissio } \\
\text { nal do } \\
\text { psicólogo } \\
\text { escolar } \\
\text { como } \\
\text { atividade } \\
\text { criadora, } \\
\text { contextua } \\
\text { lizando } \\
\text { essas } \\
\text { reflexões } \\
\text { para a } \\
\text { prática } \\
\text { desse } \\
\text { profissio } \\
\text { nal na } \\
\text { educação } \\
\text { superior. }\end{array}$ \\
\hline
\end{tabular}




\begin{tabular}{|c|c|c|c|c|c|c|c|c|c|c|}
\hline $\begin{array}{l}0 \\
8\end{array}$ & $\begin{array}{l}\text { O } \\
\text { psicólogo } \\
\text { e às } \\
\text { demanda } \\
\text { s } \\
\text { escolares } \\
\text { - } \\
\text { considera } \\
\text { ções } \\
\text { sobre a } \\
\text { formação } \\
\text { continuad } \\
\text { a }\end{array}$ & $\begin{array}{c}\text { Revista } \\
\text { Quadrim } \\
\text { estral da } \\
\text { Associaç } \\
\text { ão } \\
\text { Brasileir } \\
\text { a de } \\
\text { Psicologi } \\
\text { a Escolar } \\
\text { e } \\
\text { Educacio } \\
\text { nal }\end{array}$ & $\begin{array}{c}\text { Grat } \\
\text { uita }\end{array}$ & 09 & A1 & 03 & $\begin{array}{c}\text { Psicologi } \\
\text { a escolar; } \\
\text { formação } \\
\text { profission } \\
\text { al; } \\
\text { atuação } \\
\text { do } \\
\text { psicólogo }\end{array}$ & 38 & $\begin{array}{l}\text { Psicolo } \\
\text { gia; } \\
\text { Psicolo } \\
\text { gia } \\
\text { Educaci } \\
\text { onal }\end{array}$ & $\begin{array}{c}\text { Conhecer } \\
\text { e analisar } \\
\text { as } \\
\text { necessida } \\
\text { des de } \\
\text { formação } \\
\text { continuad } \\
\text { a de } \\
\text { psicólogo } \\
\text { s que } \\
\text { trabalha } \\
\text { m com } \\
\text { demanda } \\
\text { s } \\
\text { escolares } \\
\text { a partir } \\
\text { de sua } \\
\text { formação } \\
\text { inicial, } \\
\text { prática e } \\
\text { experiênc } \\
\text { ias de } \\
\text { formação } \\
\text { continuad } \\
\text { a, na } \\
\text { região do } \\
\text { Triângulo } \\
\text { Mineiro. }\end{array}$ \\
\hline $\begin{array}{l}0 \\
9\end{array}$ & $\begin{array}{l}\text { Núcleos } \\
\text { de } \\
\text { Acessibil } \\
\text { idade nas } \\
\text { universid } \\
\text { ades: } \\
\text { reflexões } \\
\text { a partir } \\
\text { de uma } \\
\text { experiênc } \\
\text { ia } \\
\text { institucio } \\
\text { nal. }\end{array}$ & $\begin{array}{c}\text { Revista } \\
\text { Quadrim } \\
\text { estral da } \\
\text { Associaç } \\
\text { ão } \\
\text { Brasileir } \\
\text { a de } \\
\text { Psicologi } \\
\text { a Escolar } \\
\text { e } \\
\text { Educacio } \\
\text { nal }\end{array}$ & $\begin{array}{l}\text { Grat } \\
\text { uita }\end{array}$ & 10 & A1 & 03 & $\begin{array}{c}\text { Ensino } \\
\text { superior; } \\
\text { educação } \\
\text { especial; } \\
\text { serviço de } \\
\text { apoio. }\end{array}$ & 37 & $\begin{array}{c}\text { Educaç } \\
\text { ão; } \\
\text { Inclusã } \\
\text { o } \\
\text { Ensino } \\
\text { Superio } \\
\text { r }\end{array}$ & $\begin{array}{c}\text { Descreve } \\
\text { r e } \\
\text { discutir } \\
\text { algumas } \\
\text { das ações } \\
\text { desenvol } \\
\text { vidas } \\
\text { pela } \\
\text { UFRN no } \\
\text { âmbito } \\
\text { de sua } \\
\text { política } \\
\text { de } \\
\text { inclusão } \\
\text { voltadas } \\
\text { para } \\
\text { estudante } \\
\text { s com } \\
\text { NEE, na } \\
\text { gestão } \\
2011- \\
2015 \text {, } \\
\text { bem } \\
\text { como }\end{array}$ \\
\hline
\end{tabular}




\begin{tabular}{|c|c|c|c|c|c|c|c|c|c|c|}
\hline & & & & & & & & & & $\begin{array}{c}\text { suscitar } \\
\text { algumas } \\
\text { reflexões } \\
\text { acerca do } \\
\text { trabalho } \\
\text { que a } \\
\text { universid } \\
\text { ade vem } \\
\text { desenvol } \\
\text { vendo } \\
\text { para esse } \\
\text { coletivo } \\
\text { com } \\
\text { vistas a } \\
\text { contribuir } \\
\text { com a } \\
\text { discussão } \\
\text { para o } \\
\text { aprimora } \\
\text { mento } \\
\text { dos } \\
\text { núcleos } \\
\text { de } \\
\text { acessibili } \\
\text { dade nas } \\
\text { universid } \\
\text { ades }\end{array}$ \\
\hline $\begin{array}{l}1 \\
0\end{array}$ & $\begin{array}{l}\text { Psicologi } \\
\text { a e } \\
\text { Educação } \\
: \\
\text { possibilid } \\
\text { ades de } \\
\text { atuação } \\
\text { para o } \\
\text { psicólogo } \\
\text { escolar } \\
\text { educacio } \\
\text { nal }\end{array}$ & $\begin{array}{c}\text { Percurso } \\
\text { Acadêmi } \\
\text { co - } \\
\text { Revista } \\
\text { Interdisci } \\
\text { plinar da } \\
\text { PUC } \\
\text { Minas no } \\
\text { Barreiro }\end{array}$ & $\begin{array}{l}\text { Grat } \\
\text { uita }\end{array}$ & 10 & B3 & 03 & $\begin{array}{c}\text { Psicologi } \\
\text { a escolar. } \\
\text { Desenvol } \\
\text { vimento } \\
\text { humano. } \\
\text { Educação }\end{array}$ & 15 & $\begin{array}{l}\text { Psicolo } \\
\text { gia; } \\
\text { Psicolo } \\
\text { gia da } \\
\text { Educaç } \\
\text { ão }\end{array}$ & $\begin{array}{c}\text { Investiga } \\
\text { r a } \\
\text { relação } \\
\text { entre } \\
\text { Psicologi } \\
\text { a e } \\
\text { Educação } \\
\text {, baseada } \\
\text { na } \\
\text { perspecti } \\
\text { va de } \\
\text { possibilid } \\
\text { ades de } \\
\text { inserção } \\
\text { e atuação } \\
\text { do } \\
\text { psicólogo } \\
\text { escolar } \\
\text { educacio } \\
\text { nal neste } \\
\text { âmbito } \\
\text { formativo } \\
\text {, } \\
\text { profissio } \\
\text { nal e }\end{array}$ \\
\hline
\end{tabular}




\begin{tabular}{|c|c|c|c|c|c|c|c|c|c|c|}
\hline & & & & & & & & & & $\begin{array}{c}\text { intersubje } \\
\text { tivo. }\end{array}$ \\
\hline $\begin{array}{l}1 \\
1\end{array}$ & $\begin{array}{l}\text { Atuação } \\
\text { e Práticas } \\
\text { na } \\
\text { Psicologi } \\
\text { a Escolar } \\
\text { no Brasil: } \\
\text { revisão } \\
\text { sistemáti } \\
\text { ca em } \\
\text { periódico } \\
\text { s }\end{array}$ & $\begin{array}{c}\text { Revista } \\
\text { Quadrim } \\
\text { estral de } \\
\text { Associaç } \\
\text { ão } \\
\text { Brasileir } \\
\text { a de } \\
\text { Psicologi } \\
\text { a Escolar } \\
\text { e } \\
\text { Educacio } \\
\text { nal }\end{array}$ & $\begin{array}{l}\text { Grat } \\
\text { uita }\end{array}$ & 09 & B1 & 03 & $\begin{array}{c}\text { Psicologi } \\
\text { a Escolar; } \\
\text { atuação } \\
\text { do } \\
\text { psicólogo } \\
\text {; revisão } \\
\text { de } \\
\text { literatura }\end{array}$ & 30 & $\begin{array}{l}\text { Psicolo } \\
\text { gia; } \\
\text { Psicolo } \\
\text { gia } \\
\text { Educaci } \\
\text { onal }\end{array}$ & $\begin{array}{c}\text { Apresent } \\
\text { ar } \\
\text { algumas } \\
\text { das } \\
\text { produçõe } \\
\text { s de PEE, } \\
\text { publicada } \\
\text { s de } \\
\text { janeiro } \\
\text { de } 2000 \text { a } \\
\text { setembro } \\
\text { de } 2017 \text {, } \\
\text { por meio } \\
\text { de bases } \\
\text { de } \\
\text { indexaçã } \\
\text { o de } \\
\text { revistas } \\
\text { de } \\
\text { produção } \\
\text { científica } \\
\text { que } \\
\text { sejam de } \\
\text { acesso } \\
\text { livre e } \\
\text { permitam } \\
\text { a } \\
\text { promoçã } \\
\text { o da } \\
\text { atuação } \\
\text { de } \\
\text { psicólogo } \\
\text { s na área. }\end{array}$ \\
\hline $\begin{array}{l}1 \\
2\end{array}$ & $\begin{array}{l}\text { Interventi } \\
\text { on in } \\
\text { Learning } \\
\text { Strategies } \\
\text { : Study } \\
\text { with New } \\
\text { Universit } \\
\text { y } \\
\text { Students }\end{array}$ & $\begin{array}{c}\text { Caderno } \\
\text { de } \\
\text { Graduaçã } \\
\text { o - } \\
\text { Ciências } \\
\text { Humanas } \\
\text { e Sociais } \\
\text { UNIT/A } \\
\text { L }\end{array}$ & $\begin{array}{l}\text { Grat } \\
\text { uita }\end{array}$ & 20 & B4 & 03 & $\begin{array}{l}\text { Ensino } \\
\text { Superior; } \\
\text { Psicologi } \\
\text { a Escolar; } \\
\text { Mediação }\end{array}$ & 36 & $\begin{array}{l}\text { Psicolo } \\
\text { gia } \\
\text { Educaci } \\
\text { onal; } \\
\text { social }\end{array}$ & $\begin{array}{c}\text { Identifica } \\
\text { r e } \\
\text { analisar a } \\
\text { relação } \\
\text { entre a } \\
\text { integraçãa } \\
\text { o na } \\
\text { educação } \\
\text { superior } \\
\text { e a } \\
\text { atuação } \\
\text { do } \\
\text { psicólogo } \\
\text { escolar, } \\
\text { fundame }\end{array}$ \\
\hline
\end{tabular}




\begin{tabular}{|c|c|c|c|c|c|c|c|c|c|c|}
\hline & & & & & & & & & & $\begin{array}{c}\text { ntada na } \\
\text { teoria de } \\
\text { mediação } \\
\text { de } \\
\text { Vygotsky }\end{array}$ \\
\hline $\begin{array}{l}1 \\
3\end{array}$ & $\begin{array}{l}\text { Possibilit } \\
\text { ies for } \\
\text { Interventi } \\
\text { on of the } \\
\text { School } \\
\text { Psycholo } \\
\text { gist in } \\
\text { Inclusive } \\
\text { Educatio } \\
\mathrm{n}\end{array}$ & $\begin{array}{c}\text { Paidéia } \\
\text { (Ribeirão } \\
\text { Preto. } \\
\text { Online) }\end{array}$ & $\begin{array}{l}\text { Grat } \\
\text { uita }\end{array}$ & 09 & $\mathrm{~A} 1$ & 04 & $\begin{array}{l}\text { Aprendiz } \\
\text { agem; } \\
\text { autorregul } \\
\text { ação da } \\
\text { aprendiza } \\
\text { gem; } \\
\text { psicologia } \\
\text { educacion } \\
\text { al; ensino } \\
\text { superior }\end{array}$ & 20 & $\begin{array}{l}\text { Psicolo } \\
\text { gia; } \\
\text { Psicolo } \\
\text { gia da } \\
\text { Aprendi } \\
\text { zagem }\end{array}$ & $\begin{array}{c}\text { Verificar } \\
\text { os efeitos } \\
\text { de um } \\
\text { programa } \\
\text { de } \\
\text { desenvol } \\
\text { vimento } \\
\text { de } \\
\text { estratégia } \\
\text { s de } \\
\text { aprendiza } \\
\text { gem em } \\
\text { estudante } \\
\text { s } \\
\text { universitá } \\
\text { rios. }\end{array}$ \\
\hline $\begin{array}{l}1 \\
4\end{array}$ & $\begin{array}{l}\text { Em } \\
\text { novos } \\
\text { rumos: a } \\
\text { Psicologi } \\
\text { a Escolar } \\
\text { no } \\
\text { Ensino } \\
\text { Superior }\end{array}$ & $\begin{array}{c}\text { Gerais: } \\
\text { Revista } \\
\text { Interinsti } \\
\text { tucional } \\
\text { de } \\
\text { Psicologi } \\
\text { a }\end{array}$ & $\begin{array}{l}\text { Grat } \\
\text { uita }\end{array}$ & 19 & B1 & 03 & $\begin{array}{c}\text { Inclusão } \\
\text { escolar. } \\
\text { Psicólogo } \\
\text { escolar. } \\
\text { Psicologi } \\
\text { a } \\
\text { histórico- } \\
\text { cultural. }\end{array}$ & 27 & $\begin{array}{c}\text { Psicolo } \\
\text { gia; } \\
\text { Educaç } \\
\text { ão } \\
\text { Especia } \\
1\end{array}$ & $\begin{array}{c}\text { Fazer um } \\
\text { mapeame } \\
\text { nto de } \\
\text { ações na } \\
\text { área da } \\
\text { Psicologi } \\
\text { a Escolar } \\
\text { Educacio } \\
\text { nal } \\
\text { favoreced } \\
\text { oras das } \\
\text { práticas } \\
\text { inclusiva } \\
\text { s dentro } \\
\text { das } \\
\text { escolas e } \\
\text { que, } \\
\text { efetivame } \\
\text { nte, } \\
\text { promova } \\
\text { m o } \\
\text { desenvol } \\
\text { vimento } \\
\text { dos } \\
\text { sujeitos. }\end{array}$ \\
\hline $\begin{array}{l}1 \\
5\end{array}$ & $\begin{array}{l}\text { Inovaçõe } \\
\text { s em } \\
\text { Psicologi } \\
\text { a } \\
\text { Escolar: }\end{array}$ & $\begin{array}{c}\text { Estudos } \\
\text { de } \\
\text { Psicologi } \\
\text { a }\end{array}$ & $\begin{array}{l}\text { Grat } \\
\text { uita }\end{array}$ & 14 & A1 & 03 & $\begin{array}{c}\text { Educação } \\
\text { Superior; } \\
\text { Prática } \\
\text { Institucio } \\
\text { nal; }\end{array}$ & 40 & $\begin{array}{l}\text { Psicolo } \\
\text { gia; } \\
\text { Psicolo } \\
\text { gia }\end{array}$ & $\begin{array}{l}\text { Apresent } \\
\text { ar a } \\
\text { Psicologi } \\
\text { a Escolar, } \\
\text { considera }\end{array}$ \\
\hline
\end{tabular}




\begin{tabular}{|c|c|c|c|c|c|c|c|c|c|c|}
\hline & \begin{tabular}{|l|} 
o \\
contexto \\
da \\
Educação \\
Superior.
\end{tabular} & $\begin{array}{l}\text { (Campin } \\
\text { as) }\end{array}$ & & & & & $\begin{array}{c}\text { Psicologi } \\
\text { a Escola }\end{array}$ & & $\begin{array}{c}\text { Educaci } \\
\text { onal }\end{array}$ & $\begin{array}{c}\text { da como } \\
\text { campo de } \\
\text { pesquisa, } \\
\text { reflexão, } \\
\text { produção } \\
\text { de } \\
\text { conhecim } \\
\text { ento e de } \\
\text { intervenç } \\
\text { ão } \\
\text { profissio } \\
\text { nal, } \\
\text { inserida } \\
\text { no } \\
\text { contexto } \\
\text { da } \\
\text { educação } \\
\text { superior, } \\
\text { prospecta } \\
\text { ndo } \\
\text { avanços } \\
\text { ao campo } \\
\text { científico } \\
\text { e à } \\
\text { atuação } \\
\text { profissio } \\
\text { nal na } \\
\text { área. }\end{array}$ \\
\hline $\begin{array}{l}1 \\
6\end{array}$ & $\begin{array}{l}\text { Responsa } \\
\text { bilidade } \\
\text { Social na } \\
\text { Educação } \\
\text { Superior: } \\
\text { contribui } \\
\text { ções da } \\
\text { Psicologi } \\
\text { a Escolar }\end{array}$ & $\begin{array}{c}\text { Revista } \\
\text { Semestra } \\
1 \text { da } \\
\text { Associaç } \\
\text { ão } \\
\text { Brasileir } \\
\text { a de } \\
\text { Psicologi } \\
\text { a Escolar } \\
\text { e } \\
\text { Educacio } \\
\text { nal }\end{array}$ & $\begin{array}{l}\text { Grat } \\
\text { uita }\end{array}$ & 08 & A1 & 03 & $\begin{array}{c}\text { Psicologi } \\
\text { a Escolar; } \\
\text { Responsa } \\
\text { bilidade } \\
\text { Social; } \\
\text { Educação } \\
\text { Superior }\end{array}$ & 21 & $\begin{array}{l}\text { Psicolo } \\
\text { gia; } \\
\text { Psicolo } \\
\text { gia } \\
\text { Escolar }\end{array}$ & $\begin{array}{c}\text { Apresent } \\
\text { ar a } \\
\text { sistemati } \\
\text { zação de } \\
\text { um } \\
\text { Programa } \\
\text { de } \\
\text { Responsa } \\
\text { bilidade } \\
\text { Social } \\
\text { para a } \\
\text { Educação } \\
\text { Superior } \\
\text { a partir } \\
\text { de uma } \\
\text { experiênc } \\
\text { ia de } \\
\text { pesquisa- } \\
\text { ação } \\
\text { realizada } \\
\text { por um } \\
\text { grupo de } \\
\text { três } \\
\text { psicóloga } \\
\text { s com } \\
\text { formação }\end{array}$ \\
\hline
\end{tabular}




\begin{tabular}{|c|c|c|c|c|c|c|c|c|c|c|}
\hline & & & & & & & & & & $\begin{array}{c}\text { em } \\
\text { psicologi } \\
\text { a escolar } \\
\text { de uma } \\
\text { faculdade } \\
\text { privada } \\
\text { do } \\
\text { Distrito } \\
\text { Federal, a } \\
\text { partir de } \\
\text { agora } \\
\text { nomeada } \\
\text { FT, com } \\
\text { o apoio } \\
\text { das } \\
\text { variadas } \\
\text { equipes } \\
\text { de } \\
\text { trabalho } \\
\text { da } \\
\text { instituiçã } \\
\text { o, como: } \\
\text { secretaria } \\
\text {, } \\
\text { biblioteca } \\
\text { informáti } \\
\text { ca, } \\
\text { coordena } \\
\text { ções de } \\
\text { cursos, } \\
\text { para citar } \\
\text { alguns. }\end{array}$ \\
\hline $\begin{array}{l}1 \\
7\end{array}$ & $\begin{array}{l}\text { Formaçã } \\
\text { o do } \\
\text { Psicólogo } \\
\text { para } \\
\text { atuar na } \\
\text { Educação } \\
: \\
\text { concepçõ } \\
\text { es de } \\
\text { coordena } \\
\text { dores de } \\
\text { curso. }\end{array}$ & $\begin{array}{c}\text { Psicologi } \\
\text { a: } \\
\text { Ciência e } \\
\text { Profissão }\end{array}$ & $\begin{array}{c}\text { Grat } \\
\text { uita }\end{array}$ & 15 & A2 & 05 & $\begin{array}{c}\text { Coordena } \\
\text { dores de } \\
\text { Curso, } \\
\text { Psicologi } \\
\text { a Escolar, } \\
\text { Formação } \\
\text { do } \\
\text { Psicólogo } \\
\text {, Projeto } \\
\text { Político } \\
\text { Pedagógi } \\
\text { co, } \\
\text { Psicologi } \\
\text { a e } \\
\text { Educação } \\
\text {. }\end{array}$ & 38 & $\begin{array}{l}\text { Psicolo } \\
\text { gia; } \\
\text { Psicolo } \\
\text { gia } \\
\text { Educaci } \\
\text { onal }\end{array}$ & $\begin{array}{c}\text { Analisar } \\
\text { a } \\
\text { formação } \\
\text { dada aos } \\
\text { futuros } \\
\text { psicólogo } \\
\text { s nos } \\
\text { cursos de } \\
\text { Graduaçãa } \\
\text { o em } \\
\text { Psicologi } \\
\text { a quanto } \\
\text { à ênfase } \\
\text { nos } \\
\text { processos } \\
\text { educativo } \\
\text { s, tendo } \\
\text { em vista } \\
\text { as } \\
\text { Diretrizes }\end{array}$ \\
\hline
\end{tabular}




\begin{tabular}{|c|c|c|c|c|c|c|c|c|c|c|}
\hline & & & & & & & & & & $\begin{array}{c}\text { Curricula } \\
\text { res } \\
\text { Nacionai } \\
\mathrm{s}-\mathrm{DCN} .\end{array}$ \\
\hline $\begin{array}{l}1 \\
8\end{array}$ & $\begin{array}{l}\text { Revisão } \\
\text { de } \\
\text { Literatura } \\
\text { sobre } \\
\text { Psicologi } \\
\text { a Escolar } \\
\text { na } \\
\text { educação } \\
\text { profissio } \\
\text { nal, } \\
\text { científica } \\
\text { e } \\
\text { tecnológi } \\
\text { ca }\end{array}$ & $\begin{array}{c}\text { Revista } \\
\text { Semestra } \\
1 \\
\text { Associaç } \\
\text { ão } \\
\text { Brasileir } \\
\text { a de } \\
\text { Psicologi } \\
\text { a Escolar } \\
\text { e } \\
\text { Educacio } \\
\text { nal }\end{array}$ & $\begin{array}{l}\text { Grat } \\
\text { uita }\end{array}$ & 10 & $\mathrm{~A} 1$ & 03 & $\begin{array}{l}\text { Revisão } \\
\text { de } \\
\text { literatura; } \\
\text { psicologia } \\
\text { escolar; } \\
\text { ensino } \\
\text { profission } \\
\text { alizante. }\end{array}$ & 43 & $\begin{array}{l}\text { Psicolo } \\
\text { gia; } \\
\text { Psicolo } \\
\text { gia } \\
\text { Social }\end{array}$ & $\begin{array}{c}\text { Fazer } \\
\text { uma } \\
\text { revisão } \\
\text { sistemáti } \\
\text { ca das } \\
\text { produçõe } \\
\text { s } \\
\text { acadêmic } \\
\text { as } \\
\text { relaciona } \\
\text { das à } \\
\text { inserção } \\
\text { do } \\
\text { psicólogo } \\
\text { escolar } \\
\text { na } \\
\text { educação } \\
\text { profissio } \\
\text { nal, } \\
\text { científica } \\
\text { e } \\
\text { tecnológi } \\
\text { ca no } \\
\text { contexto } \\
\text { brasileiro }\end{array}$ \\
\hline $\begin{array}{l}1 \\
9\end{array}$ & $\begin{array}{l}\text { Psicologi } \\
\text { a Escolar } \\
\text { na } \\
\text { Educação } \\
\text { Superior: } \\
\text { atuação } \\
\text { no } \\
\text { Distrito } \\
\text { Federal }\end{array}$ & $\begin{array}{c}\text { Psicologi } \\
\text { a em } \\
\text { Estudo }\end{array}$ & $\begin{array}{l}\text { Grat } \\
\text { uita }\end{array}$ & 12 & B1 & 03 & $\begin{array}{c}\text { Psicologi } \\
\text { a Escolar; } \\
\text { Educação } \\
\text { Superior; } \\
\text { atuação } \\
\text { Institucio } \\
\text { nal }\end{array}$ & 54 & $\begin{array}{l}\text { Psicolo } \\
\text { gia; } \\
\text { Psicolo } \\
\text { gia } \\
\text { Educaci } \\
\text { onal }\end{array}$ & $\begin{array}{c}\text { Mapear } \\
\text { as } \\
\text { Instituiçõ } \\
\text { es de } \\
\text { Educação } \\
\text { Superior } \\
\text { do } \\
\text { Distrito } \\
\text { Federal } \\
\text { que } \\
\text { possuem } \\
\text { Psicólogo } \\
\text { Escolar e } \\
\text { conhecer } \\
\text { e analisar } \\
\text { o } \\
\text { trabalho } \\
\text { realizado. }\end{array}$ \\
\hline
\end{tabular}




\begin{tabular}{|c|c|c|c|c|c|c|c|c|c|c|}
\hline $\begin{array}{l}2 \\
0\end{array}$ & $\begin{array}{l}\text { Formaçã } \\
\text { o de } \\
\text { psicólogo } \\
\text { s para a } \\
\text { educação } \\
: \\
\text { concepçõ } \\
\text { es de } \\
\text { docentes. }\end{array}$ & $\begin{array}{l}\text { Psicologi } \\
\text { a da } \\
\text { Educaçã } \\
\text { o }\end{array}$ & & 11 & & 05 & $\begin{array}{l}\text { Psicologi } \\
\text { a Escolar, } \\
\text { professor } \\
\text { es } \\
\text { universitá } \\
\text { rios, } \\
\text { formação } \\
\text { do } \\
\text { psicólogo } \\
\text {, } \\
\text { psicologia } \\
\text { educacion } \\
\text { al, } \\
\text { currículo }\end{array}$ & 25 & $\begin{array}{l}\text { Psicolo } \\
\text { gia; } \\
\text { Psicolo } \\
\text { gia } \\
\text { Educaci } \\
\text { onal }\end{array}$ & $\begin{array}{c}\text { Compree } \\
\text { nder as } \\
\text { concepçõ } \\
\text { es de } \\
\text { docentes } \\
\text { sobre a } \\
\text { formação } \\
\text { do } \\
\text { psicólogo } \\
\text {, com } \\
\text { destaque } \\
\text { para a } \\
\text { ênfase } \\
\text { em } \\
\text { processos } \\
\text { educativo } \\
\text { s, bem } \\
\text { como seu } \\
\text { entendim } \\
\text { ento } \\
\text { sobre as } \\
\text { repercuss } \\
\text { ões das } \\
\text { DCN no } \\
\text { cotidiano } \\
\text { dos } \\
\text { cursos de } \\
\text { Psicologi } \\
\text { a. }\end{array}$ \\
\hline $\begin{array}{l}2 \\
1\end{array}$ & $\begin{array}{l}\text { Mapeame } \\
\text { nto de } \\
\text { Competê } \\
\text { ncias do } \\
\text { Psicólogo } \\
\text { Escolar. }\end{array}$ & $\begin{array}{c}\text { Revista } \\
\text { Quadrim } \\
\text { estral da } \\
\text { Associaç } \\
\text { ão } \\
\text { Brasileir } \\
\text { a de } \\
\text { Psicologi } \\
\text { a Escolar } \\
\text { e } \\
\text { Educacio } \\
\text { nal } \\
\end{array}$ & $\begin{array}{l}\text { Grat } \\
\text { uita }\end{array}$ & 10 & A1 & 03 & $\begin{array}{c}\text { Psicologi } \\
\text { a Escolar; } \\
\text { atuação } \\
\text { do } \\
\text { psicólogo } \\
; \\
\text { competên } \\
\text { cia }\end{array}$ & 18 & $\begin{array}{l}\text { Psicolo } \\
\text { gia; } \\
\text { Psicolo } \\
\text { gia } \\
\text { Escolar }\end{array}$ & $\begin{array}{l}\text { Realizar } \\
\text { o } \\
\text { mapeame } \\
\text { nto de } \\
\text { competên } \\
\text { cias do } \\
\text { psicólogo } \\
\text { escolar }\end{array}$ \\
\hline $\begin{array}{l}2 \\
2\end{array}$ & $\begin{array}{l}\text { Identifica } \\
\text { ção de } \\
\text { necessida } \\
\text { des de } \\
\text { intervenç } \\
\text { ão } \\
\text { psicológi } \\
\text { ca: um } \\
\text { estudo- } \\
\text { piloto no }\end{array}$ & $\begin{array}{l}\text { Psicologi } \\
\text { a USP }\end{array}$ & $\begin{array}{l}\text { Grat } \\
\text { uita }\end{array}$ & 14 & & 03 & $\begin{array}{c}\text { Necessida } \\
\text { des; } \\
\text { intervenç } \\
\text { ão } \\
\text { psicológic } \\
\text { a; ensino } \\
\text { superior. }\end{array}$ & $\begin{array}{l}\text { quanti } \\
46\end{array}$ & $\begin{array}{l}\text { Psicolo } \\
\text { gia; } \\
\text { Psicolo } \\
\text { gia } \\
\text { Educaci } \\
\text { onal }\end{array}$ & $\begin{array}{c}\text { Explorar } \\
\text { as } \\
\text { necessida } \\
\text { des de } \\
\text { intervenç } \\
\text { ão } \\
\text { psicológi } \\
\text { ca dos } \\
\text { estudante } \\
\text { s da } \\
\end{array}$ \\
\hline
\end{tabular}




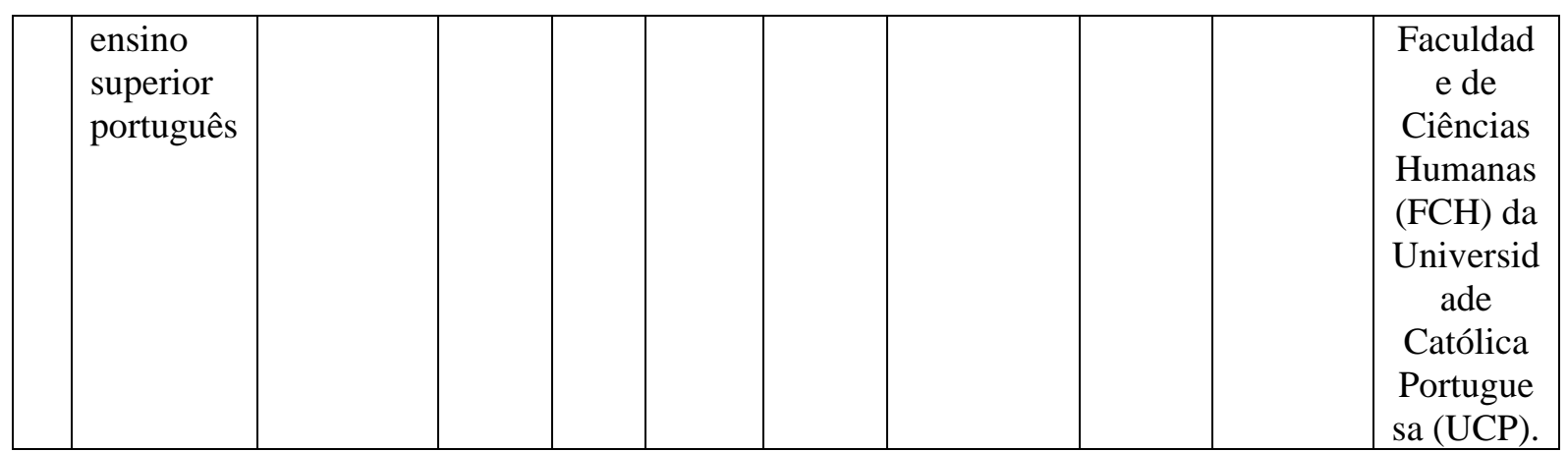

Fonte: Autoria própria.

\section{DISCUSSÃO}

\section{Bibliometria: conceitos}

Santos e Kobash (2009), citam Boustany (1997) que aponta o uso de métodos estatísticos e matemáticos para mapear informações, a partir de registros bibliográficos de documentos (livros, periódicos, artigos), não constitui fato novo.

Discorrer sobre a evolução histórica e os conceitos que diversos autores descreveram no decorrer do tempo sobre a bibliometria não é o propósito deste artigo mas para uma melhor compreensão deste tipo de pesquisa acredita ser necessário citar alguns autores que conceituam e descrevem o que vem a ser uma pesquisa bibliométrica.

Ribeiro e Santos (2017) notam o quanto as pesquisas bibliométricas vêm crescendo e evoluindo seu processo de aferição e qualidade dos dados e informações, mediante estudos divulgados em periódicos internacionais, em especial as revistas nacionais, contribuindo com isso para um entendimento e posterior compreensão macro de campos científicos e/ou temas do conhecimento em diferentes estágios de evolução.

Pimenta, Portela, Oliveira e Ribeiro (2017), citam que Otlet (1934) é um dos principais pesquisadores sobre o assunto, ele considera a bibliometria como um modo de qualificar a ciência por meio de ferramentas estatísticas, aplicadas sobre as fontes de informações. Também citam Vanti (2002), que de modo mais detalhado declara que a pesquisa bibliométrica utilizase de métodos quantitativos para possibilitar a análise da evolução e dos processos que ocorrem na produção científica, por meio da avaliação de patentes, dissertações, teses, e demais produtos da ciência.

De acordo com Ribeiro (2017), existem três nomes que embasaram as técnicas da bibliometria, são eles: Bradford, Lotka e Zipf. Cada um destes pesquisadores, podem ser identificados com uma lei específica, respectivamente.

A lei de Bradford (1934), por sua vez, trata da dispersão dos autores em diferentes publicações periódicas. A lei do 
quadrado inverso, de Lotka (1926), referese ao cálculo da produtividade de autores de artigos científicos. Em se tratando da lei de Zipf, apresentada em 1935, refere-se a frequência da ocorrência de palavras num texto longo. (SANTOS, KOBASHI, 2009)

Vosgerau e Romanowski (2014) citam Lopes (2012) que definem quatro tipos de indicadores bibliométricos: indicadores de qualidade científica, indicadores de atividade científica, indicadores de impacto científico e indicadores de associações temáticas.

Esses indicadores dariam origem às diversas variáveis contabilizadas nos A bibliometria, portanto, auxilia a verificação de muitos aspectos da comunicação científica e tecnológica; se mostra excelente ferramenta para conhecer o estado da arte das áreas do conhecimento em seus recortes específicos, como análise temporal, autoral, temática, entre outras; é bem aceita por pesquisadores de diversos campos do conhecimento, desde que se respeitem suas especificidades; os dados empíricos resultantes se mostram importantes apoios para análise quantitativa e qualitativa (JOB, 2018). estudos bibliométricos, das quais destacamos: a quantidade e evolução dos artigos publicados, tipologia dos artigos, números de páginas, autoria, colaboração científica entre as autorias, produtividade dos autores; transitoriedade dos autores; gênero e afiliação institucional e geográfica dos autores; citações realizadas pelos autores; temáticas dos artigos; autoria das citações; tipologia das fontes citadas; nível de atualização das fontes citadas; origem das fontes citadas; idiomas das fontes citadas; abrangência das fontes bibliográficas (SILVA; HAYASHI, 2013).

\section{Versão/idioma/número de páginas.}

Nesta variável há a junção das perguntas referentes a versão em que o artigo foi publicado, qual o idioma e o número de páginas por artigo. A busca retornou com $100 \%(\mathrm{n}=22)$ de publicação versão eletrônica, ou seja, versão on line. Todos os 22 artigos tiveram a publicação online. Quanto ao idioma das publicações está concentrado no idioma português, sendo 20 artigos dos 22 estão em português, isto é, $\mathrm{n}=20$ artigos (91\%), seguidos pelo idioma em inglês, que foi encontrado apenas 2 artigos, ou seja, $\mathrm{n}=2$ (9\%). 


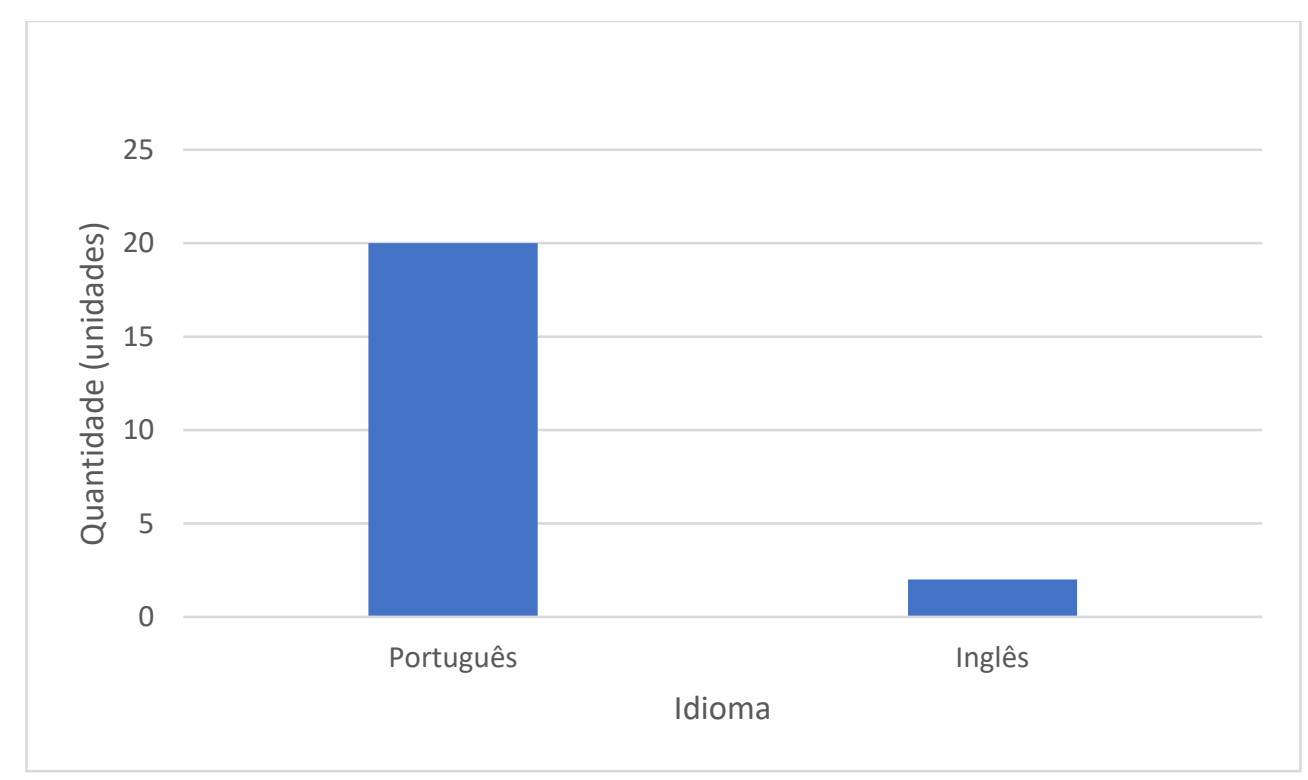

Fonte: Autoria própria.

O número de páginas por artigo contabilizou uma média de10 páginas por artigo, sendo o máximo 20 e o mínimo 7 páginas por artigo.

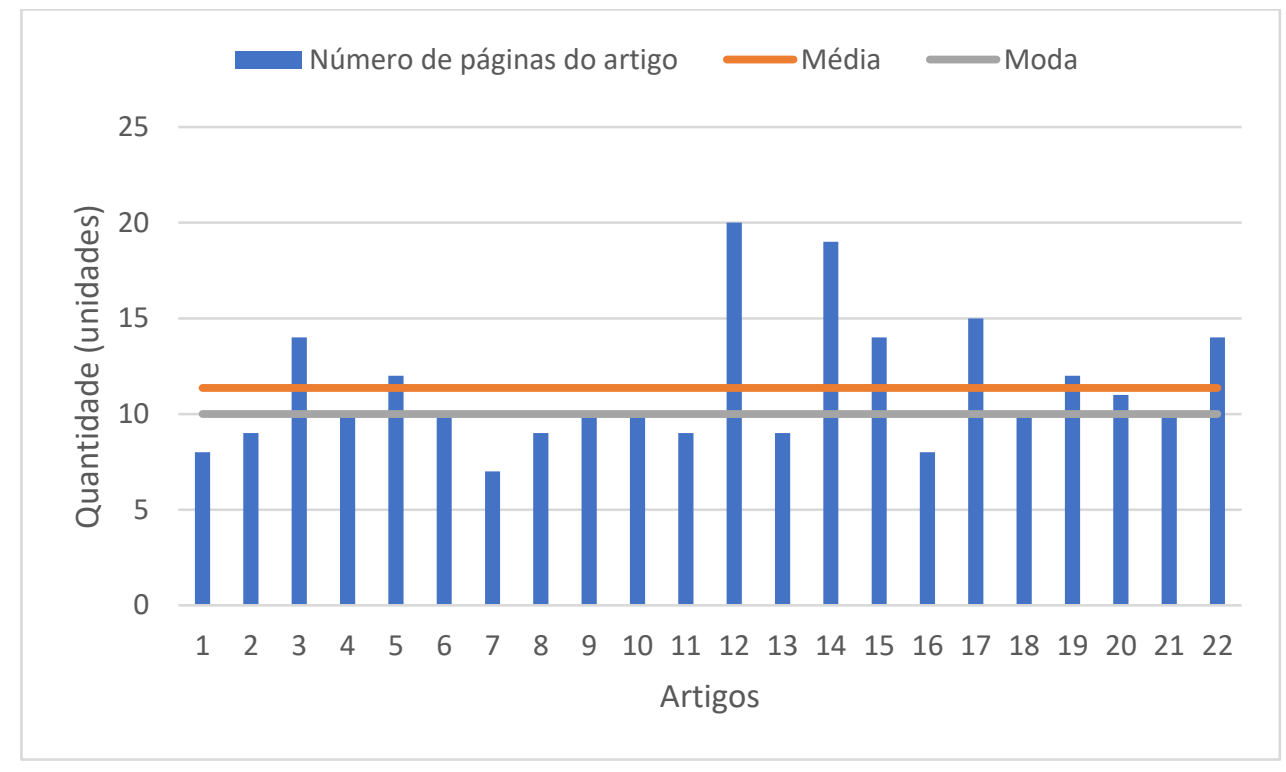

Fonte: Autoria própria

Fonseca, Gomes, Campos (2016) concordam com Gomes, Fonseca (2011) quando se referem que os gráficos em barras têm como objetivo comparar grandezas, por meio de retângulos de igual largura e alturas proporcionais às suas respectivas grandezas. É possível utilizar gráficos em barras, por exemplo, para a quantidade de páginas por edição do impresso.

\section{Publicação/autoria e coautoria}

O quesito publicação foi encontrado que o valor da publicação dos artigos nas 21 revistas $(95,45 \%)$ das 22 é gratuita e apenas 
uma revista não é identificado se é gratuito

ou paga $(4,5 \%)$.

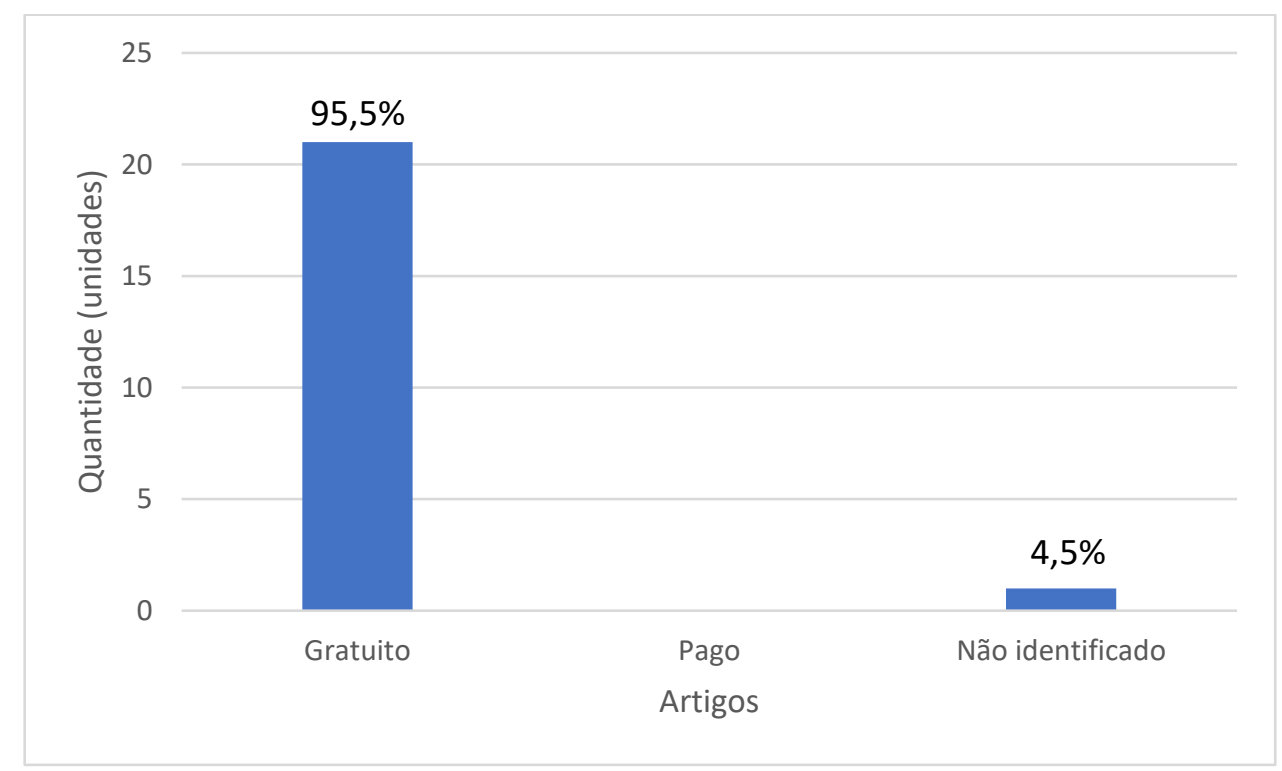

Fonte: Autoria própria

No que se refere à autoria e coautoria é identificado um total de 22 autores $(\mathrm{n}=22)$ e 46 coautores $(n=46)$ envolvidos na produção dos artigos. Determinando que a média de autores e coautores por artigo é 5 , a máxima é 6 e a mínima é 1 autor/coautor por artigo.

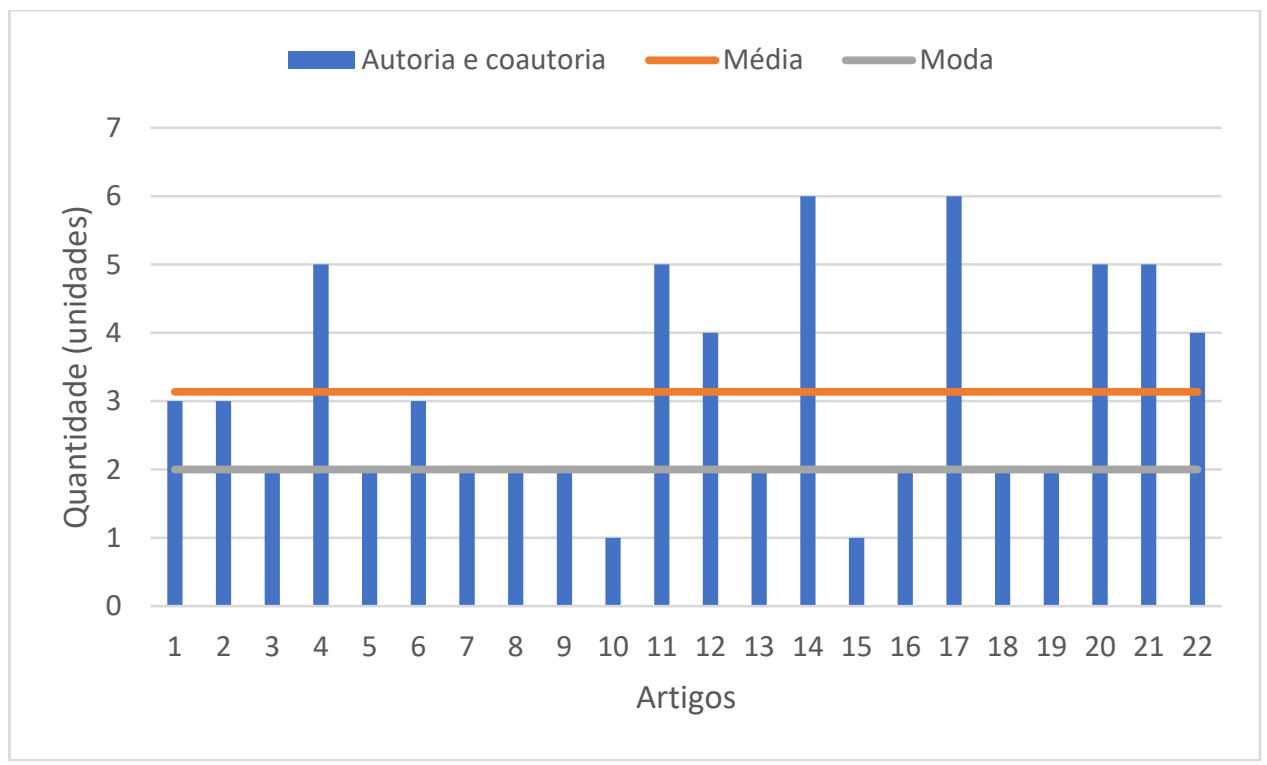

Fonte: Autoria própria

Conclui-se que a tabela acima apresenta uma representatividade bem significativa quanto à publicação ser gratuita $(95,5 \%)$ e a média de autores e coautores por artigo é de 5. Esses achados corroboram com os trabalhos de outros 
autores em outras áreas, os quais encontram uma predominância de trabalhos de autores como coautores. De acordo com Vanti (2002) um dos principais objetivos da bibliometria é medir o grau e padrões de colaboração entre autores (SILVA, et al; 2016).

No Brasil, os indicadores mais populares em artigos bibliométricos são baseados em contagem de número de artigos, número de revistas, número de autores, número de autorias, número de instituições ou número de citações
(SOARES, PICOLLI, CASAGRANDE; 2018).

\section{Qualis}

É possível observar que uma quantidade significativa das revistas/periódicos possui Qualis, dos 22 artigos $(n=22) 13$ deles se encontram em revistas com qualis A1 (59,1\%), 2 com qualis A2 (9,1\%), 2 com qualis B1 $(9,1 \%)$, 1 com qualis B3 (4,5\%) e 1 com qualis B4 $(4,5 \%)$. Detectou-se também que $13 \%$ não tinham o qualis.

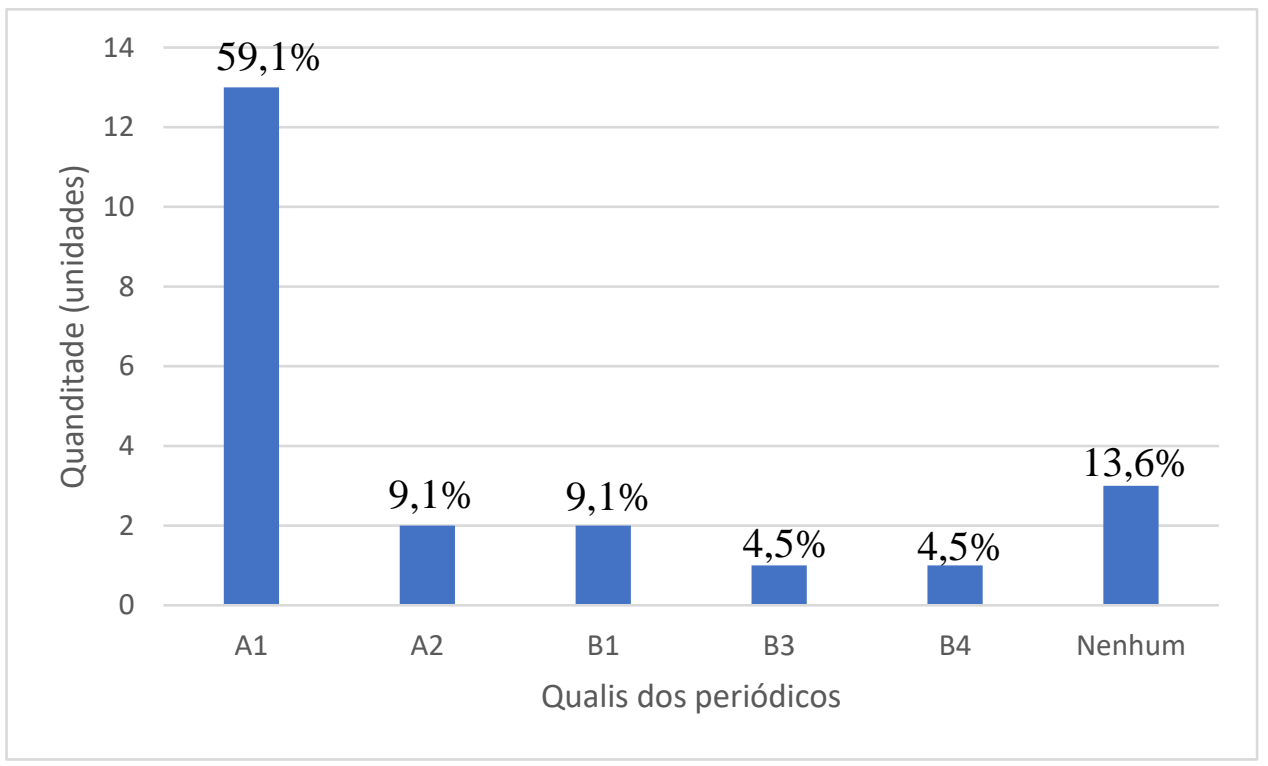

Fonte: Autoria própria

De acordo com Job (2018) é importante salientar que Qualis Periódicos é uma ferramenta empregada pelo Capes para avaliar os programas de pós-graduação brasileiros e a estratificação da qualidade dessa produção é realizada a partir de critérios estipulados em cada área. É um sistema utilizado pelo Capes e não pode ser confundido com uma base de dados bibliográfica.

As revistas recebem os seguintes graus em ordem decrescente de valor: A1; A2; B1; B2; B3; B4; B5; C (peso zero). Portanto, são conceitos para as revistas e 
não para os autores ou artigos. Não há artigo $\mathrm{A} 1$, não há autores $\mathrm{A} 2$, há sim revistas $\mathrm{A} 1$, A2 etc. (JOB,2018).

$$
\text { Para Bodart e Souza (2017) }
$$
identificar o estrato do periódico no ano de publicação nos proporcionará indicativo para a compreensão do prestígio que ocupa a temática na produção científica nacional via periódico.

\section{Palavras - chave}

Quanto as palavras-chave do resumo que permeiam os principais temas dos artigos, pode-se observar que dos 22 artigos é citada 72 palavras-chave. As palavras-chave mais utilizadas, de modo ranqueado, é Psicologia Escolar $(58,1 \%)$, Ensino Superior $(22,6 \%)$ e Atuação do Psicólogo (19,4\%).

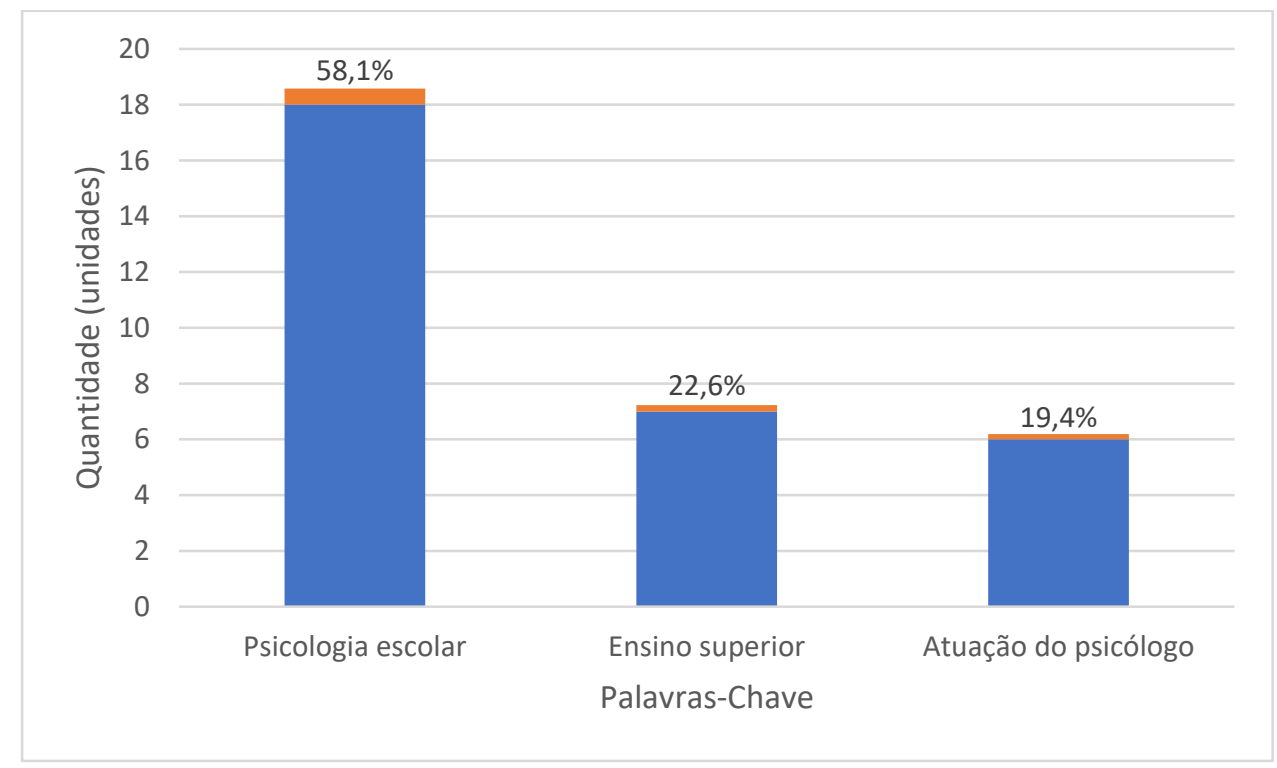

Fonte: Autoria própria

\subsubsection{Referências bibliográficas}

Nas referências bibliográficas identifica-se um total de 741 referências bibliográficas, sendo 669 em português e 72 em inglês. Desse total a média encontrada é de 38, a máxima é 54 e a mínima é 15 referências bibliográficas por artigo.

Em relação as referências em português a média é 38 , a máxima é 52 e a mínima é 6 referências. Já em inglês a média é de 1, sendo a máxima de 34 e mínima de 1 referência bibliográfica por artigo. Com esses dados percebe-se que há pouca utilização de referências bibliográficas internacionais e quando há, predomina o inglês. Em termos de porcentagem as referências em português é $90,3 \%$ e em inglês é $9,7 \%$. 


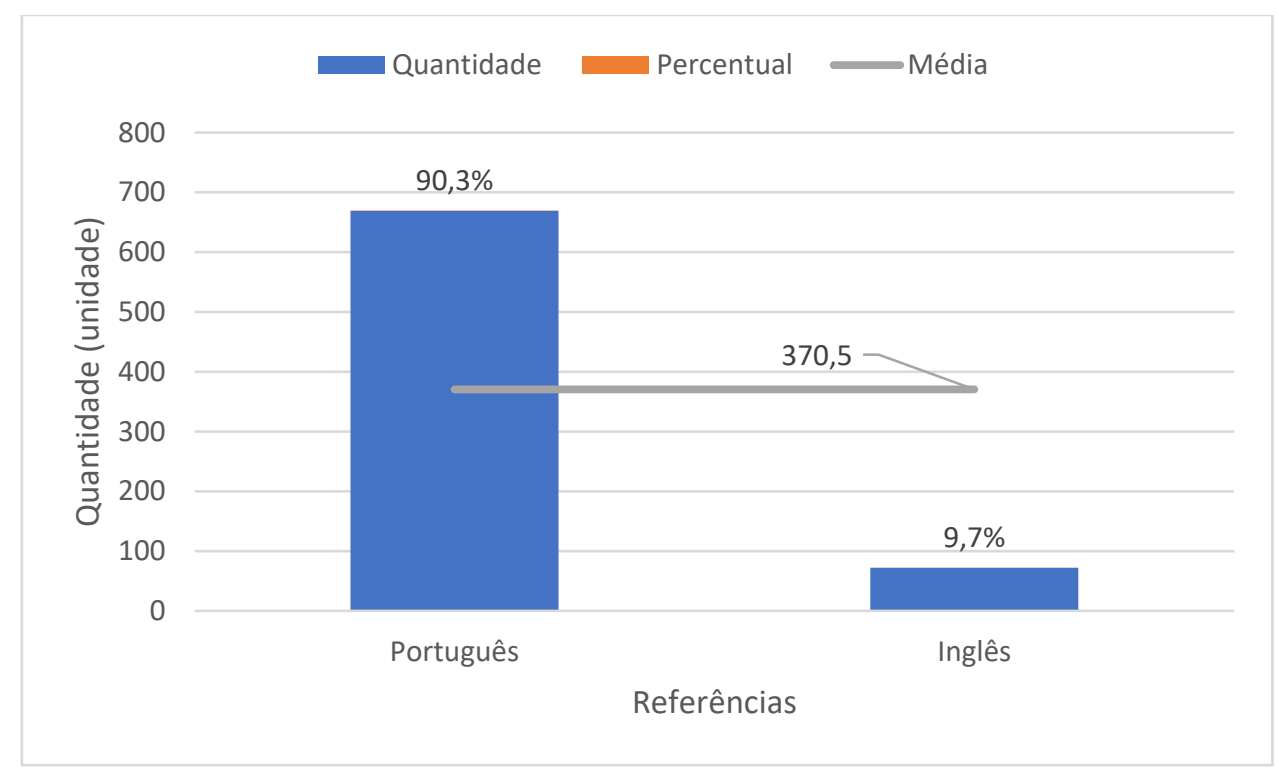

Fonte: Autoria própria

Partir do pressuposto que as referências bibliográficas são resultado de uma pesquisa bibliográfica e que esta constitui-se buscar conhecer, analisar e explicar contribuições sobre determinado assunto, tema ou problema. Entra em concordância com Soares, Picolli e Casagrande (2018) que citam Gil (2017) que concorda com Martins e Theóphilo (2016) ao argumentarem que a pesquisa bibliográfica constitui uma etapa preliminar de praticamente toda a pesquisa acadêmica. Acrescenta também que quase toda tese ou dissertação desenvolvida, atualmente, contém um capítulo ou seção dedicado à revisão bibliográfica com o duplo propósito de fornecer fundamentação teórica, bem como identificar o estágio atual do conhecimento de determinado tema.

\section{Tipo de Artigo/Natureza da Pesquisa}

No quesito tipo de artigo, a predominância foi de $100 \%$ artigo de revisão $(\mathrm{n}=22 * 100 \%)$. Em relação a natureza de pesquisa destacou-se a qualitativa com $95,5 \%$ e a quantitativa com $4,5 \%$.

Como referem Ferreira, 2002; Nóbrega-Therrien e Therrien, 2004; Romanovsky e Ens, 2006; Rother, 2006, para realizar estudos que visam mapear um campo de conhecimento, existem diversos métodos, os quais têm recebido as mais variadas denominações: levantamento bibliográfico, revisão de literatura, estado da arte, estado do conhecimento, estado da questão, revisão narrativa, revisão integrativa, revisão sistemática, metanálise, entre outros (HAYASHI e GONÇALVES, 2018). 
Para Vosgerau e Romanowki (2014)

as revisões são necessárias para pesquisadores iniciantes em uma determinada área do conhecimento. Esses estudos podem conter, análises destinadas a comparar pesquisas sobre temas semelhantes ou relacionados; apontar a evolução das teorias, dos aportes teórico metodológicos e sua compreensão em diferentes contextos, indicar as tendências e procedimentos metodológicos utilizadas na área, apontar tendências das abordagens das práticas educativas.

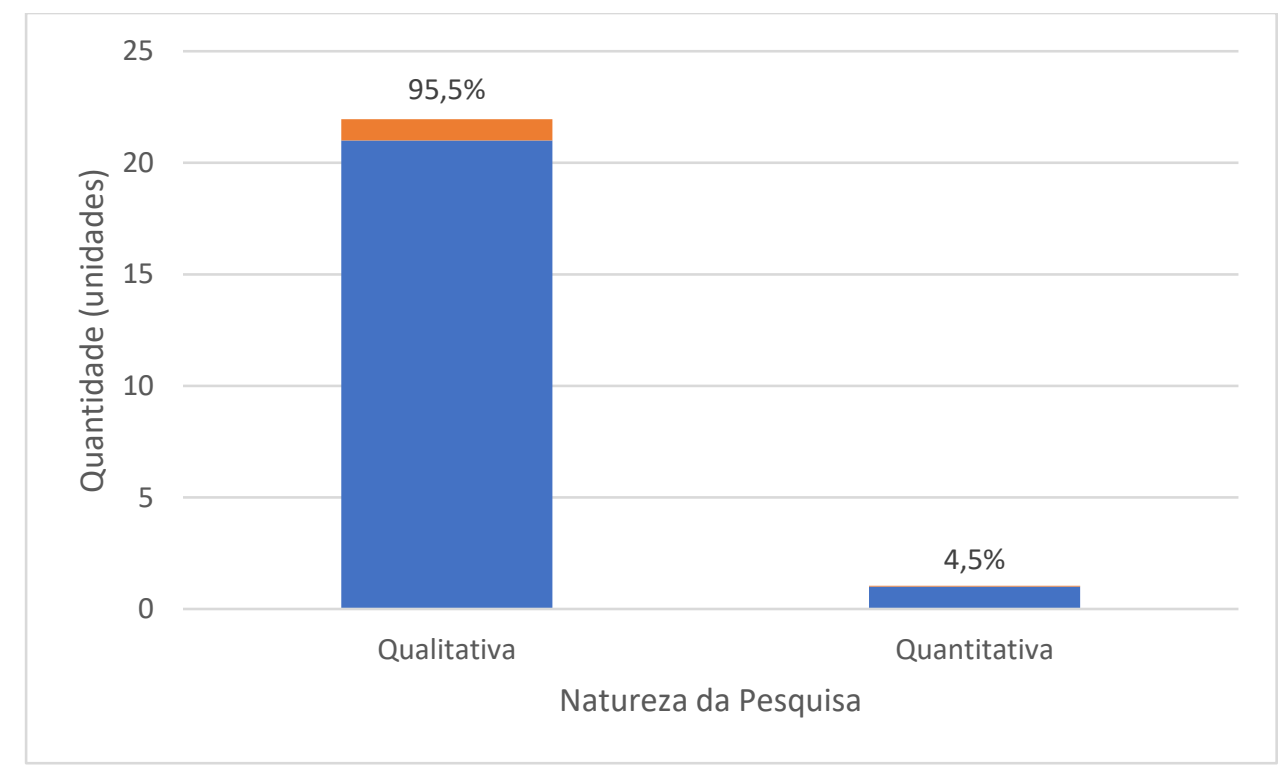

Fonte: Autoria própria

\section{Revista/Periódico}

Identificou-se

que

a

periodicidade das revistas em que os 22

artigos foram publicados, obteve-se 13

revistas

com

periodicidade

quadrimestral $(59,1 \%), 3$ revistas com periodicidade semestral $(13,6 \%), 1$ revista com periodicidade trimestral $(4,5 \%)$ e 5 revistas não foram identificadas a periodicidade $(22,7 \%)$. 


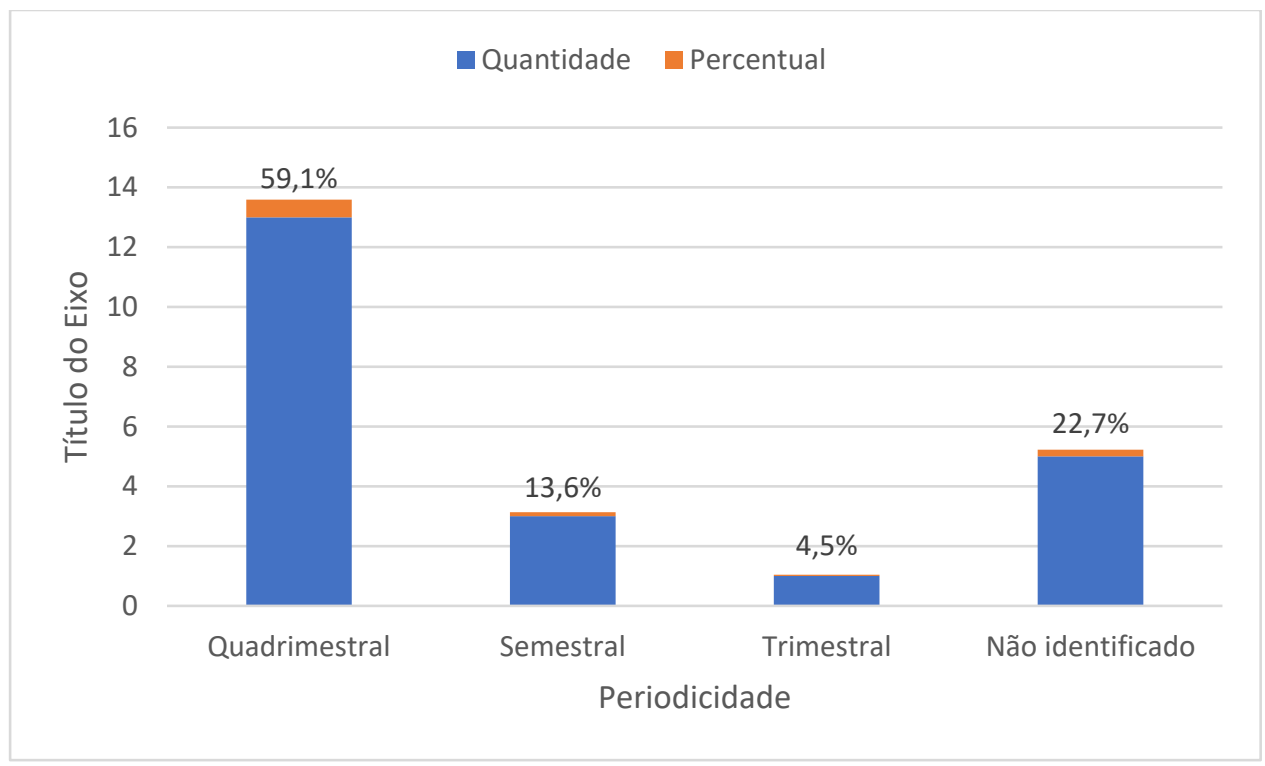

Fonte: Autoria própria

Um dado importante para ser destacado é que no total de 22 artigos, 13 deles foram publicados na Revista Quadrimestral da Associação Brasileira de Psicologia Escolar e Educacional e 3 publicados na Revista Semestral da
Associação Brasileira de Psicologia Escolar, totalizando uma percentagem de $72 \%$. Importante lembrar que a revista é a mesma e só muda a periodicidade, porque só a partir de 2014 que esta revista passa a ter a periodicidade quadrimestral.

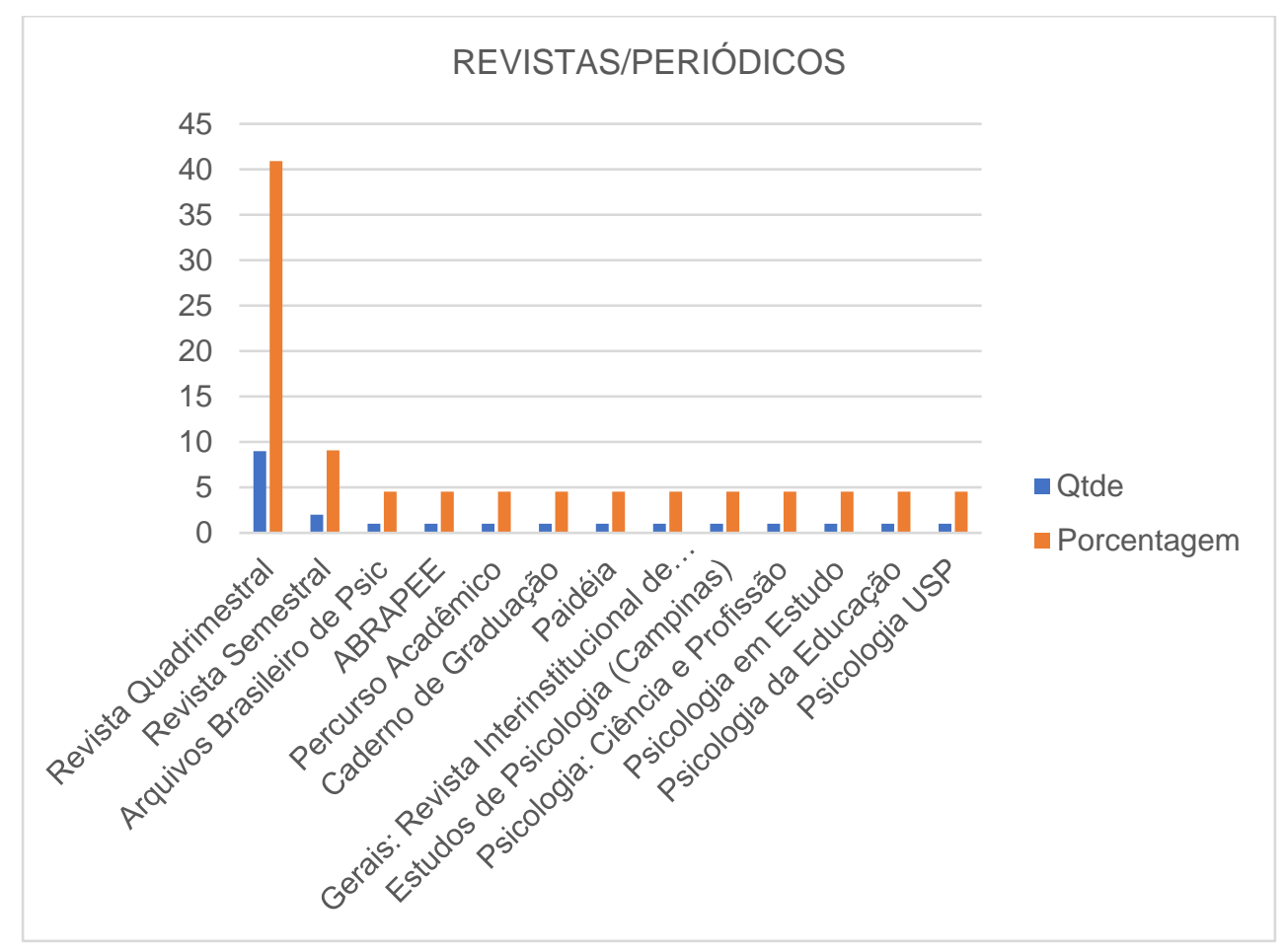

Fonte: Autoria própria 
Devido o resultado ter apresentado uma porcentagem significativa para a Revista da Associação Brasileira de Psicologia Escolar e Educacional, acredita ser importante discorrer um pouco sobre ela.

A Revista da Associação Brasileira de Psicologia Escolar e Educacional é editada pela ABRAPEE, que foi fundada em 1990 por um grupo de psicólogos interessados em congregar os estudiosos e profissionais da área, visando o reconhecimento legal da necessidade do psicólogo escolar nas instituições de ensino, bem como estimular e divulgar pesquisas nas áreas de psicologia escolar e educacional.

A Associação Brasileira de Psicologia Escolar e Educacional é uma sociedade civil, sem fins lucrativos, que tem por finalidade incentivar o crescimento da ciência e da profissão de psicólogo escolar e educacional, como um meio de promover o bem-estar e o desenvolvimento humano, enfocando para isto o processo educacional no seu sentido mais amplo.

A Revista Psicologia Escolar e Educacional, editada pela ABRAPEEAssociação Brasileira de Psicologia Escolar e Educacional publica manuscritos referentes à atuação, formação e história da Psicologia no campo da educação, textos de reflexão crítica sobre a produção acadêmico-científica e relatos de pesquisas nas áreas de Psicologia Escolar e Educacional bem como na sua interface com a educação.

A partir de 2014 a Revista Psicologia Escolar e Educacional passou a ter periodicidade quadrimestral e formato exclusivamente eletrônico. Em 2015 foi avaliada como A2 pelos critérios da área de Psicologia na CAPES. E as normas editoriais em português, inglês e espanhol são informadas pela revista.

Concordando com Ribeiro e Santos (2017) quando cita a Lei de Bradford, como a lei que mensura as revistas acadêmicas, mediante seu comportamento na literatura cientifica sobre determinado tema e/ou área do conhecimento (OSMA, 2006), isto é, a referida lei ajuda a entender e compreender a importância destes periódicos para a difusão e socialização de pesquisas bibliométricos na bibliografia acadêmica.

\subsubsection{Submissão/aceite/publicação}

Em relação ao número de artigos que constavam a data de submissão, aceite e publicação dos trabalhos, é calculada a porcentagem. Nem todos os artigos apresentavam a data de submissão, aceite e publicação, o que demonstra que não há uma rigorosidade metódica significativa, como elemento importante para a manutenção da indexação. 
Nos gráficos a seguir identifica-se um total de 13 artigos com a data de submissão, 12 com a data de aceite e $10 \mathrm{com}$ a data de publicação. Já Cunha e Pianezzola (2016) descreve em sua pesquisa um resultado oposto, onde todos os artigos apresentavam a data de submissão e aceite, o que demonstra uma rigorosidade metódica significativa, como elemento importante para a manutenção da indexação, segundo as normas estabelecidas pela SciELO.

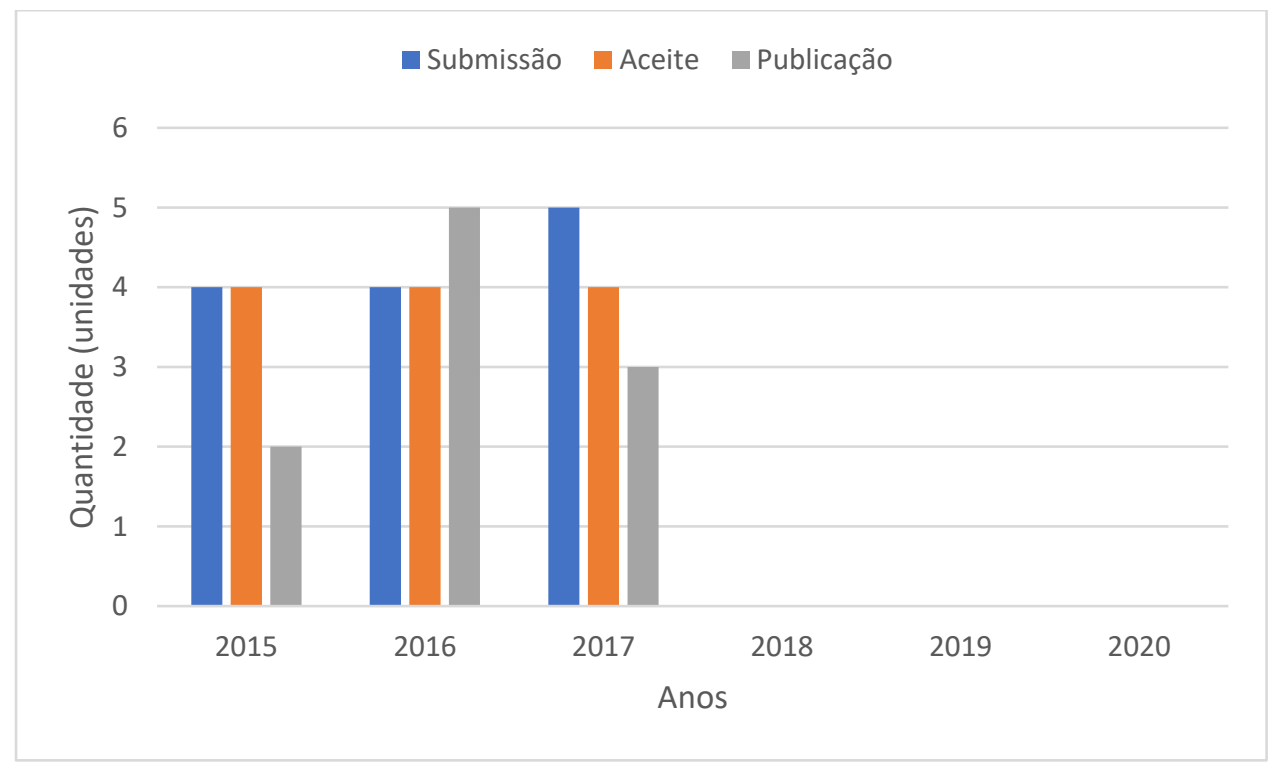

Fonte: Autoria própria

Observa-se no gráfico abaixo os que não contiveram a informação relativa à artigos que contiveram a informação e os data de submissão, aceite e publicação.

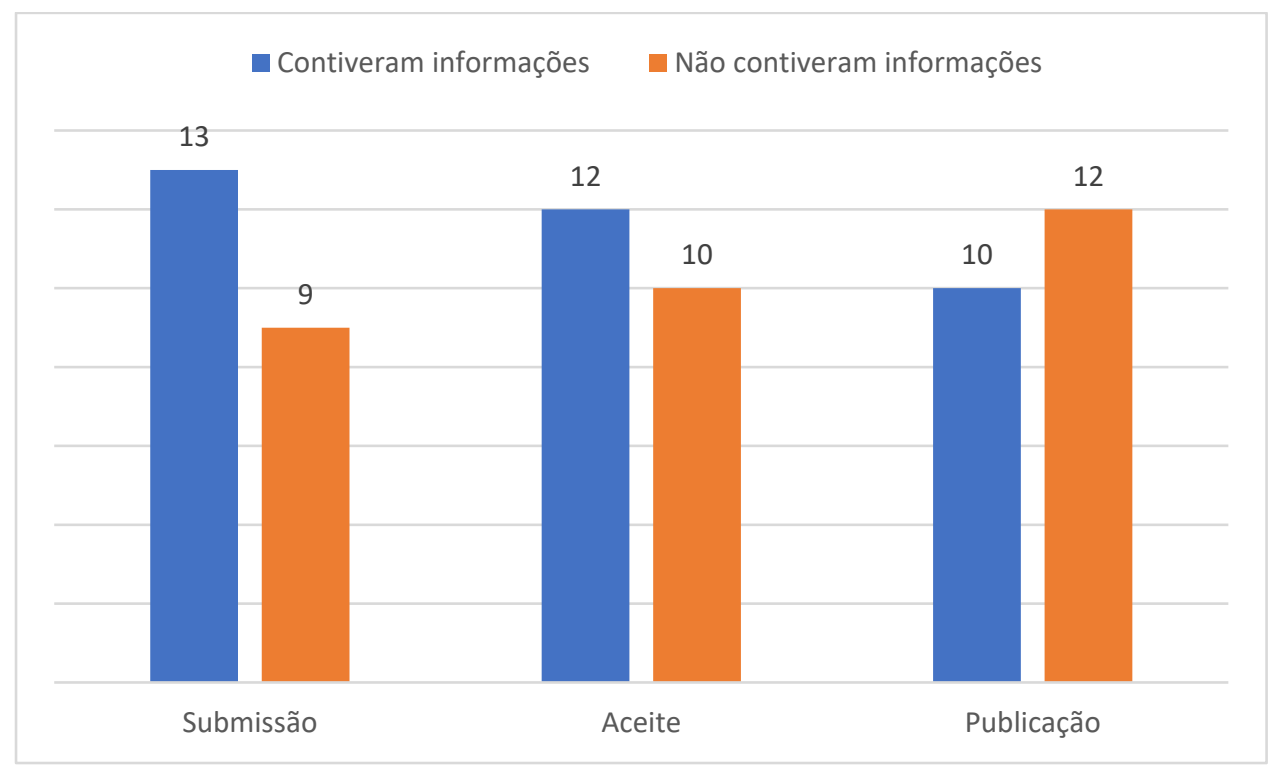

Fonte: Autoria própria 
Pimenta, Portela, Oliveira e Ribeiro (2017), descrevem que para Wolfram (2017) a bibliometria como metodologia iniciou-se com a finalidade de avaliar e entender o desempenho das atividades de produção científica acadêmica, utilizando para tanto uma quantidade de dados referentes ao período pesquisado para a extração das informações necessárias.

No

quesito

submissão/aceite/publicação dialoga e concorda com os autores acima citados, quando dizem que a bibliometria facilita quanto a utilizar uma quantidade de dados de um determinado período e retirar as informações necessárias.

A publicação de artigos é uma forma de divulgação do conhecimento científico acerca do tema que o pesquisador estudou, sendo de grande utilidade para a sociedade, principalmente para a academia ter conhecimento daquilo que está sendo discutido (VENDRAMIN, ARAÚJO; 2016).

\section{Função do autor e titulação do autor}

Quanto à função dos autores e coautores dos artigos, em números absolutos é possível identificar a função mais representativa que é a de professor efetivo, 11 (73,3\%), seguido pela função de pesquisador, $2(13,3 \%)$, mestrando $1(6,7 \%)$ e professor substituto $1(6,7 \%)$. A função com maior representatividade na amostra analisada é a de professor efetivo.

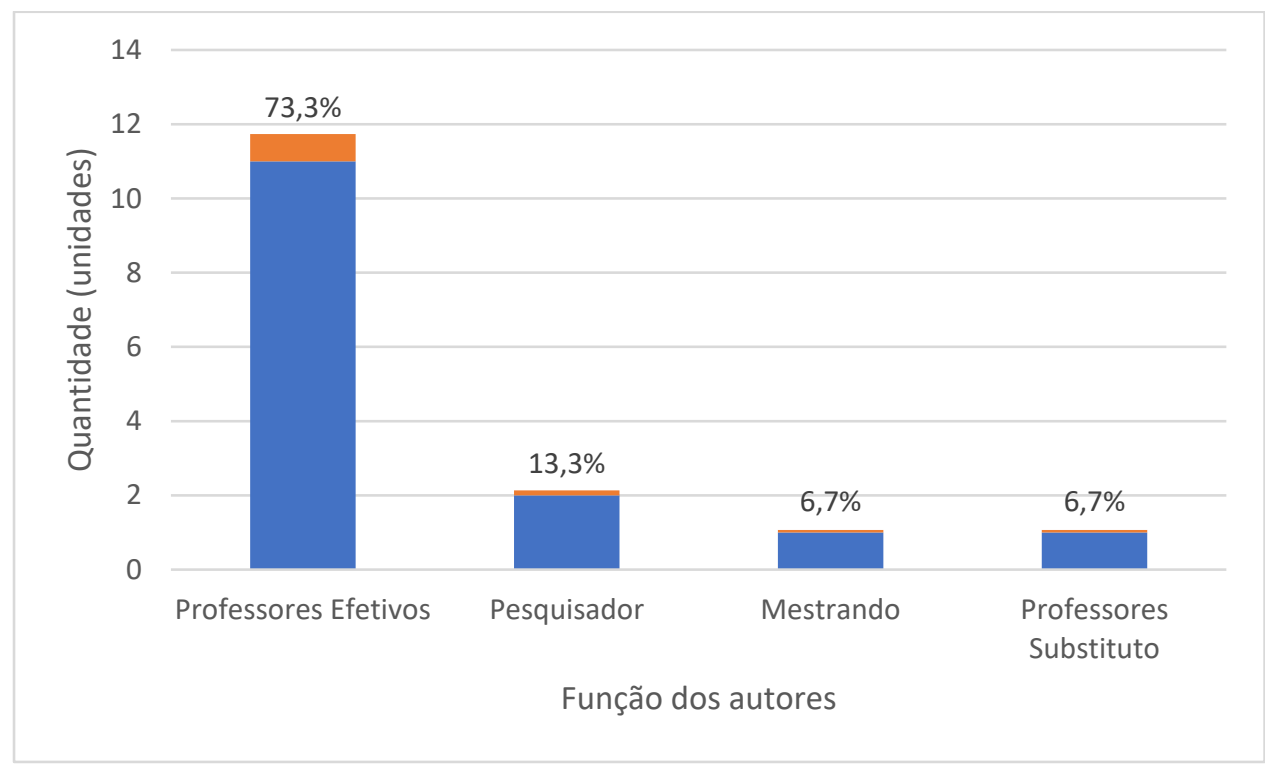

Fonte: Autoria própria

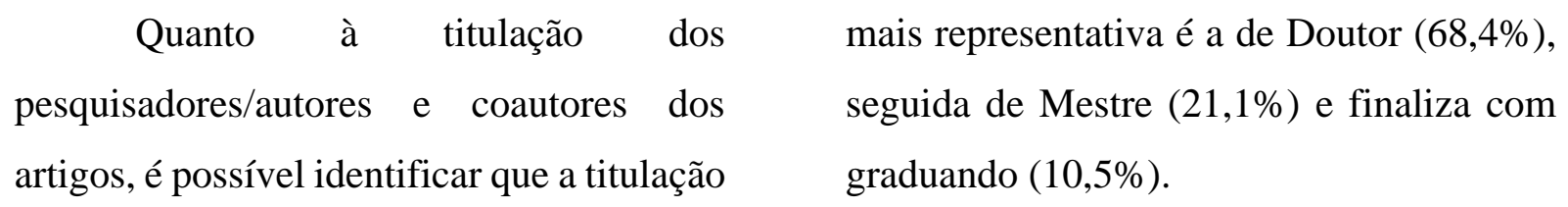




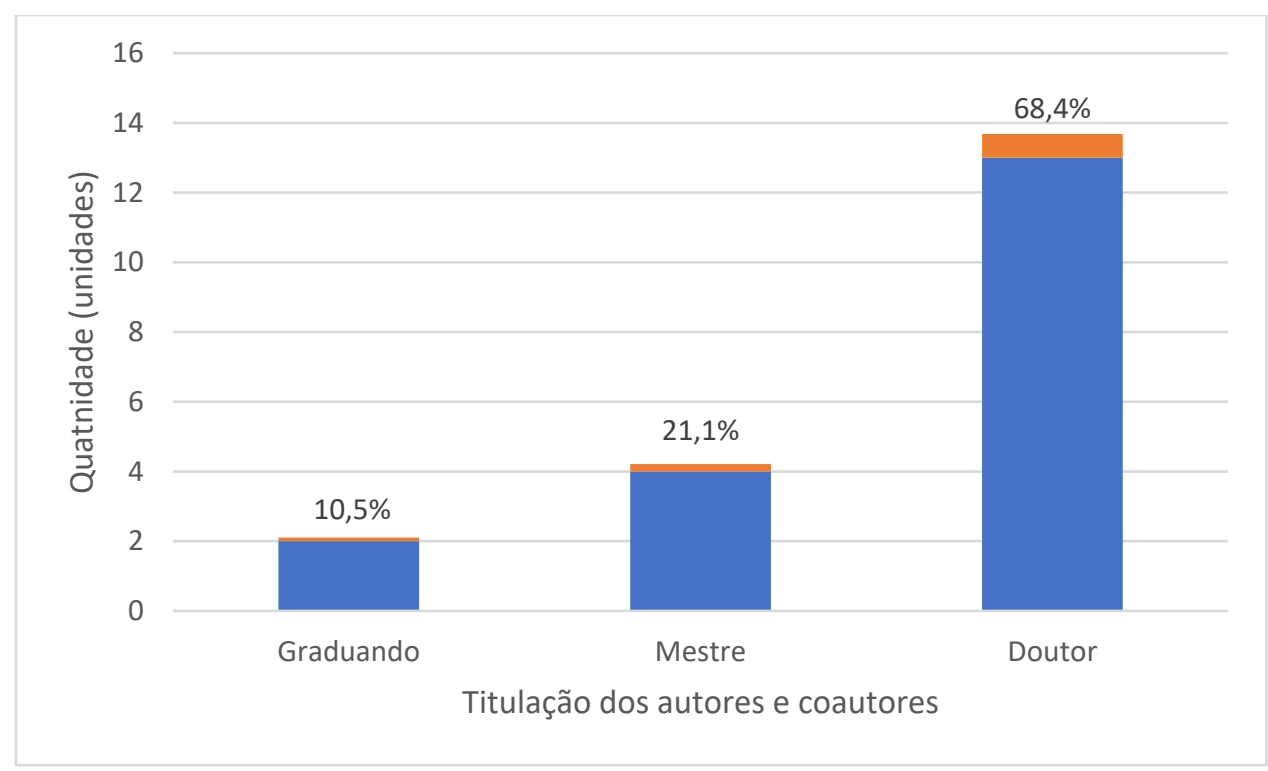

Fonte: Autoria própria.

As variáveis função e titulação vem confirmar a importância da utilização da bibliometria para analisar os dados, pois de acordo com Araújo (2006, p. 13) a bibliometria consiste na "[...] aplicação de técnicas estatísticas e matemáticas para descrever aspectos da literatura e de outros meios de comunicação (análise quantitativa da informação) ", e a “[...] diferença essencial entre a tradicional bibliografia e a bibliometria é que esta utiliza mais métodos quantitativos do que discursivos (MORAES, AMBONI, KALNIN, 2017).

A observação da titulação do autor, sua vinculação institucional e o sexo nos parece ser um meio de observarmos se tal temática é tida como secundária ou periférica, como destacaram algumas pesquisas em torno da constituição desse subcampo (BODART, SOUZA; 2017)

\subsubsection{Linha de Pesquisa}

Foi possível analisar o corpo textual da linha de pesquisa dos artigos por meio do programa software Nuvem de Palavras elaboradas na plataforma online WordArt (Figura 2), e exportar as palavras que apresentaram frequência total $(F)$ igual ou superior a 02 , isto é, mais recorrentes e que obtiveram maior relevância. 
Figura 2. Nuvem de palavras da linha de pesquisa elaboradas na Plataforma on line WordArt

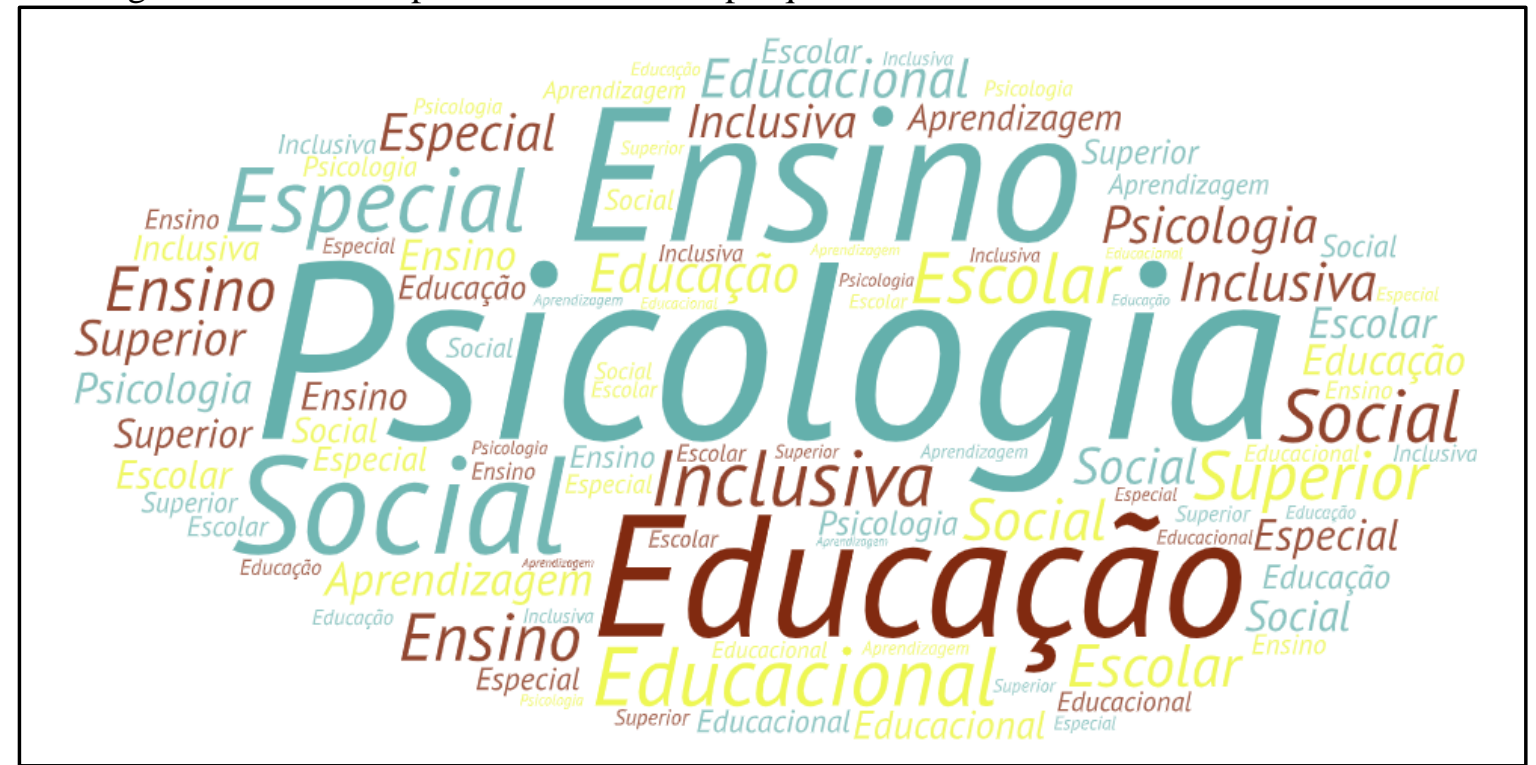

Fonte: Autoria própria

Através da Figura 2, é possível observar que as categorias PSICOLOGIA, ENSINO, EDUCAÇÃO e SOCIAL está no centro de todos os artigos utilizados neste trabalho para a análise de dados. As demais categorias derivam das categorias acima citadas, que diz respeito a outras linhas de pesquisas.

$$
\text { Vendramin e Araújo (2016) }
$$
identificam um ponto importante para uma linha de pesquisa assertiva que é o de estar integrado à sociedade sem se deixar influenciar por ela, ou seja, o pesquisador não pode deixar esse conhecimento da realidade guiar seus estudos, ele deve buscar as bases teóricas que influenciam essa realidade a ponto de propor mudanças de melhoria. Eles também recorrem à Borges-Andrade (2003) para citarem que um pesquisador deve definir sua linha de pesquisa em três esferas: i) enquanto membro de um programa de pós-graduação, ii) enquanto membro de um grupo de pesquisa, e iii) no registro de seu currículo. $\mathrm{O}$ esperado é que haja coerência nas três esferas, indicando que o pesquisador segue determinada linha de pesquisa. Entretanto, em muitos casos não se encontra essa coesão.

\section{Objetivo Geral}

Também foi possível analisar o corpo textual dos objetivos gerais dos artigos por meio do programa software Nuvem de Palavras elaboradas na plataforma online WordArt (Figura 5), e exportar as palavras que apresentaram frequência total $(F)$ igual ou superior a 02, isto é, mais recorrentes e que obtiveram maior relevância. 
$\mathrm{Na}$ Figura 3, destacam-se as no centro de todos os artigos utilizados palavras ESCOLAR, PSICOLOGIA, neste trabalho para a análise de dados. EDUCAÇÃO, PROFISSIONAL, As demais variáveis derivam das ANALISAR, AÇÕES, FORMAÇÃO, categorias acima citadas, que diz respeito a POSSIBILIDADES, SUPERIOR, outros objetivos gerais destacados nos ATUAÇÃO E PSICÓLOGO são palavras que se encontram nos objetivos gerais dos artigos em maior proporção e por isso estão artigos. Tanto a linha de pesquisa como os objetivos gerais estão sintonizados com o tema proposto dos artigos.

Figura 3. Nuvem de palavras dos objetivos gerais elaboradas na Plataforma online WordArt.

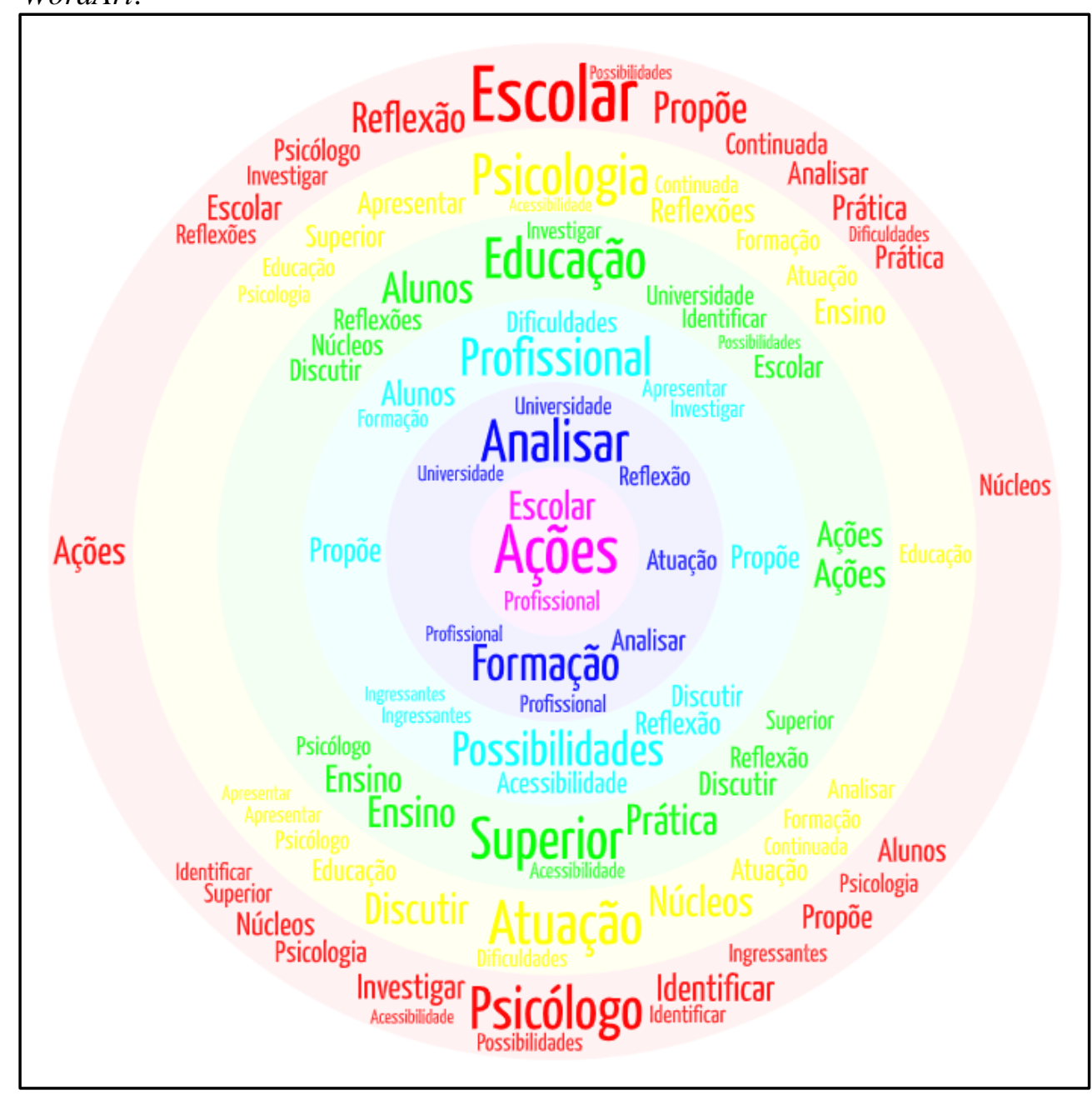

Fonte: autoria própria.

Estas discussões corroboram com Silva, Hayashi e Hayashi (2011) quando citam que a análise bibliométrica é fundamentada na premissa da contagem estatística de elementos bibliográficos presentes na literatura científica que se quer analisar. 
O que implica em produzir indicadores bibliométricos de produção científica, tais como aqueles relacionados às características dos autores (por exemplo, gênero, vinculação institucional, formação acadêmica, produtividade), das autorias (individual ou coautoria, colaboração científica), das publicações (tais como, temporalidade, tipologia, área de

\section{CONCLUSÃO}

Apresentado de forma didática os resultados analisados e discutidos é possível identificar o padrão da produção científica sobre o campo Psicologia Escolar no Ensino Superior, no período de 2013 a 2020, alcançando assim um processo que auxilie os pesquisadores da área de Educação e Psicologia na busca das fontes para coleta e organização de dados.

O estudo evidencia 12 variáveis relevantes para produção científica. Dentre elas o quesito versão de publicação totalizou $100 \%$ em formato exclusivamente eletrônico/on line. Quanto ao idioma a prevalência se deu para o idioma em português com $91 \%$. Em relação ao número de páginas por artigo foi contabilizado uma média de 10 páginas.

No que se refere à publicação, autoria e coautoria. Os resultados obtidos apresentam uma representatividade bem significativa quanto à publicação ser conhecimento, classificação de periódicos), bem como indicadores de citações (documentos citados e citantes, idade, vida média e obsolescência da literatura, fator de impacto das publicações) e indicadores de ligação (entre eles, a coocorrência de autorias, de citações e de palavras) (HAYASHI e GONÇALVES,2018).

gratuita $(95,45 \%)$ e a média de autores e coautores por artigo ser 5 .

Este estudo contribui para evidenciar um panorama dos artigos divulgados nas revistas Qualis Capes, foi apresentado as opções A1, A2, B1, B2, B3, B4, B5 e C e o resultado obtido é que há maior concentração em A1 com $n=13$ $(68,42 \%)$.

Os resultados acima apontaram para uma tendência significativa no número de publicações versando sobre o tema analisado, em publicações eletrônicas e gratuita, o conceito da revista/periódico prevalece o Qualis A1, demonstra a importância da discussão dentro da comunidade cientifica. A limitação desta pesquisa é ter trabalhado somente os artigos das áreas de Educação e Psicologia Escolar.

Quanto aos aspectos metodológicos, é encontrado em média 3 palavras chave por artigo, as mais utilizadas são Psicologia Escolar (58,06\%), Ensino Superior (22,58\%) e Atuação do Psicólogo (19,35\%), 
a natureza da pesquisa destacou-se a qualitativa (95\%).

Há uma predominância de 100\% quanto ao artigo ser de revisão, esse cenário leva-nos a concordar com Vosgerau e Romanowki (2014) de que os estudos de revisão na área de Educação embora sejam necessários e fundamentais, ainda carecem de maior aprimoramento na sua execução, conforme demonstram as análises realizadas.

As referências utilizadas foram originadas de diversas fontes e contabilizam ao todo uma média de 38 referências bibliográficas, sendo que as referências em português são em média 38 e a de inglês é em média 1. Constatando que neste campo predomina as referências nacionais.

Quanto as palavras-chave que permeiam os principais temas dos artigos, pode-se observar que as mais utilizadas, de modo ranqueado, é Psicologia Escolar 18, (58,06\%), Ensino Superior 07, (22,58\%) e Atuação do Psicólogo 6, (19,35\%). Importante salientar que essa predominância valoriza a sintonia entre os artigos e a temática.

Verificou-se que as revistas/periódicos na qual os artigos foram publicados, $50 \%$ das publicações se deu na Revista Quadrimestral/Semestral da Associação Brasileira de Psicologia Escolar e Educacional e os outros $50 \%$ foi dividido entre as outras revistas e periódicos. Torna evidente que é uma revista requisitada para publicações com alcance na comunidade científica, embasando e oferecendo subsídios para a ampliação das discussões no campo da educação e psicologia.

Identifica-se que nem todos os artigos apresentavam a data de submissão, aceite e publicação, o que demonstra que não há uma rigorosidade metódica significativa. A ausência dessas informações pode gerar vieses na pesquisa e comprometer a produção de evidências cientificamente válidas a partir das sínteses de pesquisas realizadas nesses estudos.

$\mathrm{Na}$ categoria função dos pesquisadores/autores e coautores dos artigos, em números absolutos é possível identificar que a função mais representativa é a de professor efetivo, 11 (7333,3\%), e a menos representativa a de professor substituto 1 (666,7\%). Já no quesito titulação a mais representativa é a de Doutor $(6842,1 \%)$.

Para finalizar, o corpo textual das variáveis linha de pesquisa e objetivos gerais dos artigos é analisado por meio do programa software Nuvem de Palavras elaboradas na plataforma online WordArt. As palavras PSICOLOGIA, ENSINO, EDUCAÇÃO e SOCIAL e as palavras ESCOLAR, PSICOLOGIA, EDUCAÇÃO, PROFISSIONAL, ANALISAR, AÇÕES, 
FORMAÇÃO, POSSIBILIDADES, SUPERIOR, ATUAÇÃO E PSICÓLOGO encontram-se no centro da linha de pesquisa e dos objetivos gerais de todos os artigos utilizados neste trabalho para a análise de dados.

Importante frisar que as análises aqui efetuadas não esgotam as possibilidades de investigação do assunto e nem se propuseram a tal fim. Reconhece-se as limitações do estudo e que a qualidade das pesquisas não pode ser avaliada exclusivamente por indicadores bibliométricos.

Apesar desses limites, este tipo de estudo é importante e necessário para que se possa acompanhar a produção do conhecimento, áreas/campos de conhecimento acerca da temática.

Numa análise geral, este artigo mostrou as principais etapas necessárias para operacionalizar uma produção científica e ao mesmo tempo não poderia se furtar a algumas sugestões com o objetivo de contribuir para aperfeiçoar as pesquisas e possibilitar também a avaliação de sua construção.

De acordo com Schimitt (2017) "Estes mapeamentos, além de tornarem-se fundamentais para acompanhar o desenvolvimento de uma área de conhecimento, evidenciam lacunas que poderão ser sanadas por estudos futuros",
As sugestões se referem a uma atenção e um maior rigor para os aspectos metodológicos das revisões por parte dos autores; normas editoriais para a colocação das datas de submissão, aceite e publicação de artigos de revisão formuladas de modo mais explícito - incluindo também a ampliação do total de páginas, e inclusão de mais referências internacionais.

Desse modo, entende-se que o texto possui atributos capazes de dar um suporte metodológico para aqueles que almejem construir uma estrutura de trabalho científico que permita obter resultados mais consistentes nos futuros textos que vierem a serem produzidos utilizando o estudo bibliométrico como metodologia. Diante do exposto, julga-se que a aplicação da técnica de bibliometria se mostra adequada para identificar as categorias primordiais da produção em revistas e periódicos científicos sobre a temática acima citada, porém a pesquisa apresenta limitações. É necessário reafirmar que as análises foram aplicadas a uma amostra obtida por 22 artigos, não podendo, assim, serem generalizadas.

Por fim, acredita-se que os dados contidos neste estudo alcançaram o objetivo proposto no sentido de que podem ser utilizados como ferramenta tanto para o planejamento de uma produção científica quanto reconhecer que a bibliometria é um 
dos métodos importantes para apresentar o estágio em que a pesquisa se encontra em uma determinada área e revelam-se eficientes quando os dados são

\section{REFERÊNCIAS}

ANDRÉS, A. Measuring academic research: How to undertake a bibliometric study. Elsevier, 2009.

BARRETO, M.C; AMBONI, N; KALNIN, G. F. Produção acadêmica em avaliação do ensino superior no Brasil Revista da Avaliação da Educação Superior (Campinas) Dez 2017, Volume $22 \mathrm{~N}^{\circ} 3$ Páginas $697-717$.

FREGADOLLI, A.M.V. Protocolo de Estudos Bibliométricos, instrumento investigativo, ferramenta do Google Drive em formato de Formulário Eletrônico

HAYASHI, M. C.; GONÇALVES, P.I. LIDUENHA, T. G. G. Estudo Bibliométrico dos Balanços da Produção Científica em Educação Especial na Revista Brasileira de Educação Especial (1999-2017). Revista Brasileira de Educação Especial 2018, Volume $24 \mathrm{~N}^{\circ}$ spe Páginas 135 - 152.

JOB, I. Bibliometria aplicada aos estudos do campo da Educação Física: confiabilidade, qualidade e relevância nas publicações. Motrivivência: revista de educação física, esporte e lazer, 01 July 2018, Vol.30(54), pp.18-34.

MARICATO, J.M. Procedimentos metodológicos em estudos bibliométricos e cientométricos: opções e reflexões no contexto dos processos de recuperação e organização da informação. In: COSTA, R. L. M. (Ed.). Estudos contemporâneos em comunicações e artes: melhores teses e dissertações da ECA/USP. São Paulo: ECA/USP, 2011. p. 1-19. detalhadamente trabalhados e eficazes quando cautelosamente analisados.

PIMENTA, A.A; PORTELA, A.R.M.R; OLIVEIRA, C.B; RIBEIRO, RM. A Bibliometria nas Pesquisas Acadêmicas. Revista de Ensino Pesquisa e Extensão, vol.4, $\mathrm{n}^{\circ}$ 7, 2017.

RIBEIRO, H.C.M; SANTOS, M.C. Artigos Bibliométricos: Produção Acadêmica divulgada nos Periódicos Nacionais sob a ótica da análise de Rede social. Revista Gestão universitária na América Latina, 01 January 2017, Vol.10(2), pp.229-248

RIBEIRO, H.C.M. Bibliometria: quinze anos de análise da produção acadêmica em periódicos brasileiros No 69 (2017) • http://biblios.pitt.edu/

DOI 10.5195/biblios.2017.393.

SANTOS, R. N. M.; KOBASHI, Nair Yumiko. Bibliometria, Cientometria, Infometria: Conceitos e Aplicações. Tendências da Pesquisa Brasileira em Ciência da Informação, 2009.

SCHIMITT, B. D. S. et al. Produção Científica Sobre Esporte Adaptado e Paralímpico em Periódicos Brasileiros da Educação Física. Kinesis, Santa Maria, v.35, n. 2, p. 68-79, 2017.

SILVA, F. Q; SANTOS, E.B. A; BRANDÃO, M.M; VILS, L. Estudo Bibliométrico: Orientações sobre sua Aplicação. Revista brasileira de marketing, 01 June 2016, Vol.15(2), pp.246-262.

SILVA, R. C.; HAYASHI, M. C. P. I. Revista Educação Especial: um estudo bibliométrico da produção científica no campo da Educação Especial. Revista Educação Especial, v. 21, n. 31, p. 117-136, 2013. Disponível em: $<$ http://cascavel.ufsm.br/revistas/ojs2.2.2/i 
ndex.php/educacaoespecial/article/view/15

>. Acesso em: 3 nov. 2013.

SILVA, R.C; HAYASHI, M.C.P.I. Revista

Educação Especial: um estudo bibliométrico da produção científica no campo da Educação Especial Revista "Educação Especial” n. 31, p. 117-136,
2008, Santa Maria Disponível em: http://www.ufsm.br/ce/revista.

VOSGERAU, D. S.R; ROMANOWSKI, J.P. Estudos de revisão: implicações conceituais e metodológicas. doi: 10.7213/dialogo.educ.14. 041.DS08. ISSN 1518-3483. 